\title{
Review \\ Advances in the Fate of Rare Earth Elements, REE, in Transitional Environments: Coasts and Estuaries
}

\author{
Michele Arienzo ${ }^{1, *(\mathbb{C},}$, Luciano Ferrara ${ }^{2}$, Marco Trifuoggi $^{2}\left(\mathbb{D}\right.$ and Maria Toscanesi ${ }^{2}(\mathbb{C}$ \\ 1 Department of Earth Sciences, Environment and Resources, University of Naples Federico II, Via Cintia 21, \\ 80126 Naples, Italy \\ 2 Department of Chemical Sciences, University of Naples Federico II, Via Cintia 21, 80126 Naples, Italy; \\ luciano.ferrara@unina.it (L.F.); marco.trifuoggi@unina.it (M.T.); maria.toscanesi@unina.it (M.T.) \\ * Correspondence: michele.arienzo@unina.it; Tel.: +39-081-2538166
}

Citation: Arienzo, M.; Ferrara, L. Trifuoggi, M.; Toscanesi, M. Advances in the Fate of Rare Earth Elements, REE, in Transitional Environments: Coasts and Estuaries. Water 2022, 14, 401. https://doi.org/ 10.3390/w14030401

Academic Editors: Michael Twiss and David Widory

Received: 16 November 2021

Accepted: 26 January 2022

Published: 28 January 2022

Publisher's Note: MDPI stays neutral with regard to jurisdictional claims in published maps and institutional affiliations.

Copyright: (C) 2022 by the authors. Licensee MDPI, Basel, Switzerland. This article is an open access article distributed under the terms and conditions of the Creative Commons Attribution (CC BY) license (https:// creativecommons.org/licenses/by/ $4.0 /)$.

\begin{abstract}
The production of rare earth elements, REE, has significantly increased over the past years, in parallel with the latest advances in nanotechnologies and representing a new group of emerging contaminants. They find application in construction, transport, agriculture, electronics, catalysis, and biomedicine. Their extraordinary intrinsic characteristics are fundamental for overcoming current technological challenges. The accumulation of REE is consistent in near-shore waters being affected by runoff, wastewater discharge, and proximity to built-up areas. Bioavailability in water, sediments, and accumulation in marine biota as well their endocrine disruptor effect is mostly unknown. There is a significant gap of knowledge on the ecotoxicological behaviour of REE in marine areas. The existing investigations have been performed inside well-mixed estuarine systems, due to complex hydrodynamics and multiple sediment transport situations. This hampers the definition of regulatory thresholds for REE concentrations and emissions. The review summarizes the existing information on REE geochemistry and physicochemical conditions influencing dissolution, surface complexation reactions, and distribution at the continent-ocean interface, as well as their speciation, bioavailability, and detrimental effects on living organisms. Strategies for reducing REE usage and inputs are also discussed.
\end{abstract}

Keywords: rare earth elements; estuaries; coastal environment; distribution; speciation; environmental tracers; bioaccumulation; ecotoxicity; fluxes controlling strategies

\section{Introduction}

REE are less than $20 \%$ of all elements naturally occurring in the environment [1]. They are defined as a group of 17 elements comprising scandium (Sc), yttrium (Y), and lanthanum (La) elements of group 3B of Periodic Table, and the 14 elements of the lanthanides series, Ce, Pr, Nd, Pm, Sm, Eu, Gd, Tb, Dy, Ho, Er, Tm, Yb, and Lu. Lanthanides have a very similar electronic configuration, with two external s electrons, an internal d electron, and 1 to 14 more internal $\mathrm{f}$ electrons, giving rise to a group of very similar elements. Therefore, REE have substantially similar physicochemical properties due to their electronic structure [2]. They have +3 oxidation state, are quite stable, and show contraction, with gradual decline in the ionic radius with increasing atomic number [3]. REE are highly reactive due to their electronic configuration [4]. They have low solubility and easily precipitate or form complexes with hydroxide, carbonate, fluoride, phosphates, or humic and fulvic acids [5-7].

All these elements tend to be found together in the same ores $[8,9]$. Two further groups are identified: light rare earth elements, LREE from La to Eu, and heavy rare earth elements, HREE, from Gd to Lu and Y [8]. Y, because of its low atomic weight, should be among the LREE, but it is classified with the HREE due to the similarity of its properties, due to its cation $\mathrm{Y}^{3+}$, and radius between Dy and Ho, and deposits with those of this second group [10]. Sc represents the lightest REE, but it is not classified in any of these REE 
groups because of its absence in the same deposits [10] and because of the difference of its properties with respect to both LREE and HREE [11].

Another classification of the Australian Industry Commission [12], primarily used in mineral extraction terminology, divides REE in three groups: light REE, La, Ce, Pr, Nd, and Pm; medium REE, Sm, Eu, and Gd; heavy REE, Tb, Dy, Ho, Er, Tm, Yb, Lu, Sc, and Y. A mention also deserves the classification of the U.S. Geological Survey (USGS) [13], which is like that of IUPAC [14], considering $\mathrm{La}, \mathrm{Ce}, \mathrm{Pr}, \mathrm{Nd}, \mathrm{Pr}, \mathrm{Sm}, \mathrm{Eu}$, and Gd as LRE, and Tb, Dy, $\mathrm{Ho}, \mathrm{Er}, \mathrm{Tm}, \mathrm{Yb}$, and $\mathrm{Lu}$ as HREE.

REE have similar chemical characteristics [15], i.e., most of them exist in the trivalent oxidation state, and their atomic, physical, and chemical properties vary gradually along the series [16]. In the environment, LREE tend to have higher affinities for particles, while HREE are more readily complexed by dissolved ligands [17]. Ce and Eu are atypical and have additional oxidation states, i.e., Ce (VI) and Eu (II) [3].

REE are classified as critical resource materials for high technology industrial applications [18]. REE represent nowadays extremely important ingredients in all high-technology gadgets, and for this reason, they are defined as the vitamins of modern industry [19].

Thus, even though REE in the environment come mainly from geogenic sources, their provenance from high tech devices, agriculture, and medicine is growing steadily. REE have in fact many applications as catalytic converters, Ce; permanent magnets, $\mathrm{Pr}, \mathrm{Nd}$, $\mathrm{Dy}, \mathrm{Ho}$; batteries, La, Ce, Nd; or magnetic resonance imaging, MRI, agent, Gd; and some REE are also used in the development of drugs for cancer treatment [20-22]. They are applied in military defence systems, lighters, flints, fluorescent lamps, high-tech, hightemperature superconductors, information storage, and agricultural products [23-25]. They are indispensable in emerging clean energy [26], and hence they are fundamental for the current transition from traditional energy sources to clean energy technologies, wind turbines, electric vehicles, and energy-efficient lighting [27]. The demand for REE from green technologies will reach 51.9 kilotonnes, as rare earth ores in 2030, especially of $\mathrm{Nd}$ and Dy [26].

They are in use in agriculture, forestry, animal husbandry, and aquaculture [28] and to increase meat digestibility and quality in diet supplemented with REE-enriched yeast [29]. In China, REE find application as fertilizer supplements to increase yields and crop quality [30]. Lanthanides in the surface soil layer of China reached 100-200 mg $/ \mathrm{kg}$ [31], with bioaccumulation consequences [32,33]. Asia-namely, in China-shows the most critical risk of REE pollution level, followed by Europe, Africa, USA, and Australia [34].

Due to such large use, the world consumption of REE in 2020 was $540 \mathrm{kt}$ and is continuously increasing by $6 \%$ each year $[10,35]$.

The two flows of REE, natural and anthropic, may exert cumulative and synergic damaging effects [36], that alter the natural REE distribution [23], especially in natural aquatic systems, disturbing biogeochemical cycles.

REE are recent contaminants, and this limits the knowledge about their environmental fate in terms of bioaccumulation, bioavailability, and toxicity. For this reason, environmental discharge of REE is usually not regulated by governments. Moreover, diffuse REE inputs from the air and water runoff from hard-standing areas hinders the set-up of regulation rules especially in estuaries that receive different input from their catchments $[36,37]$. The literature displays $[37,38]$ that only wastes and treated water from mining activities are embedded in three European regulations, establishing threshold concentrations of REE, EIA directive/EU1452/; Directive/EU 0621/; Directive/EU 1359/ [38]

Thus, REE in aquatic environments, must be considered as ubiquitous contaminants; the presence has already been measured in waters, suspended particles, and sediments of rivers [39], estuaries [40], and oceans [41,42]. REE have been detected in coastal areas at trace concentrations [43]; however, their harmful ecosystem effects have been only hypothesised [44]. In the marine environment, REE may interact with the resident biota by different pathways. They can bioaccumulate in organisms and be further transferred along the trophic web, resulting in biomagnification or bio-dilution in the upper trophic lev- 
els [37]. Environmental concentrations of the fractionated pools of REE, LREE, and HREE, normalized to reference reservoirs, i.e., chondrite, shales, makes it possible to highlight geochemical processes, tracer water masses, and anthropic releases [45-47], as is often the case of Sm and Gd showing positive anomalies in many estuaries of the world [48]. Anthropogenic anomalies of $\mathrm{Gd}, \mathrm{La}$, and $\mathrm{Sa}$ in aqueous samples are often reported [49]. Following anthropogenic $\mathrm{Gd}$, the anomalies of $\mathrm{La}, \mathrm{Sa}$, and Eu are reported [50]. The positive $\mathrm{Gd}$ anomalies reported for river waters worldwide are caused by the large use of Gd-based contrast agents used in magnetic resonance imaging (MRI) [50]. Sm finds applications in many different areas, from high-strength permanent magnets to control rods in nuclear reactors, and it is used as a catalyst in assisting the decomposition of plastics and the dechlorination of polychlorinated biphenyls [49]. A survey of the anthropogenic dissolved and colloid/nanoparticle-bound Gd and Sm in the Rhine River suggests that while the anthropogenic $\mathrm{Gd}$ is not particle-reactive, and hence exclusively present in the truly dissolved REE pool, the anthropogenic Sm is also present in the colloidal/nanoparticulate REE pool [49].

Sholkovitz [51,52] reports that there is fractionation of REE during the formation of weathering products from parent rocks and that weathered products accumulate REE and tend to be LREE-enriched relative to the parent rock. Fractionation is due, in part, to the formation of more soluble HREE-complexes that are transported away from the weathering zone and to the preferential retention of the LREE by adsorption to or incorporation into secondary minerals. The same author [51,52] states that the solution pool of REE in river waters is strongly HREE-enriched and is fractionated to the same extent as that of surface seawater. This means that the evolved REE composition of sea water is coupled to chemical weathering on the continents and reactions in estuaries. A particular behaviour is shown by Ce and Eu having valency of +2 besides +3 , and +4 as well as +3 , respectively influencing the solubility and stability of compounds and hence of anomalies in the REE patterns. It is known that most waters show negative $\mathrm{Ce}$ and $\mathrm{Eu}$ anomalies [16].

The research on the behaviour of REE in marine estuaries and coastal environments is developing. The core of the review is to present the existing information on REE behaviour and on fate processes in estuaries and coastal environments.

\subsection{The Natural Abundance}

The discovery of REE occurred in 1787, but it was not published by Arrhenius until the following year [53]. Their magnetic, luminescent, and electrochemical value has been estimated only few decades ago [54]. The "rare" definition does not reflect their abundance in the environment, which is higher than those of gold or copper, Figure 1, but the form in which they occur, dispersed in ores instead of in the native form of aggregates or nuggets $[55,56]$.

REE are widely distributed in the Earth's crust in average concentrations ranging from 150 to $220 \mathrm{mg} / \mathrm{kg}$ [57], which is significantly higher than other commonly exploited elements and much higher than their respective chondritic abundances [58].

The mean total crustal abundance of REE is $169 \mathrm{mg} / \mathrm{kg}$, and LREE, La to Gd, are $137.8 \mathrm{mg} / \mathrm{kg}$, far higher than HREE, $31.34 \mathrm{mg} / \mathrm{kg}$. The most abundant REE in the Earth crust are Ce and La, $63 \mathrm{mg} / \mathrm{kg}$ and $31 \mathrm{mg} / \mathrm{kg}$, a presence richer than those of $\mathrm{Cu}, 28 \mathrm{mg} / \mathrm{kg}$, and $\mathrm{Pb}, 17 \mathrm{mg} / \mathrm{kg}$ [59]. The rarest ones are $\mathrm{Tm}$ and $\mathrm{Lu}$, with levels of $0.30 \mathrm{mg} / \mathrm{kg}$ and $0.31 \mathrm{mg} / \mathrm{kg}$, respectively, higher than those of $\mathrm{Au}, 0.0015 \mathrm{mg} / \mathrm{kg}, \mathrm{Ag}, 0.053 \mathrm{mg} / \mathrm{kg}$, and platinum group elements [59]. According to the Oddo-Harkin rule, the REE abundance is greater for those with an even atomic number compared with those with an odd atomic number, and abundance decreases through the lanthanide series [3]. 


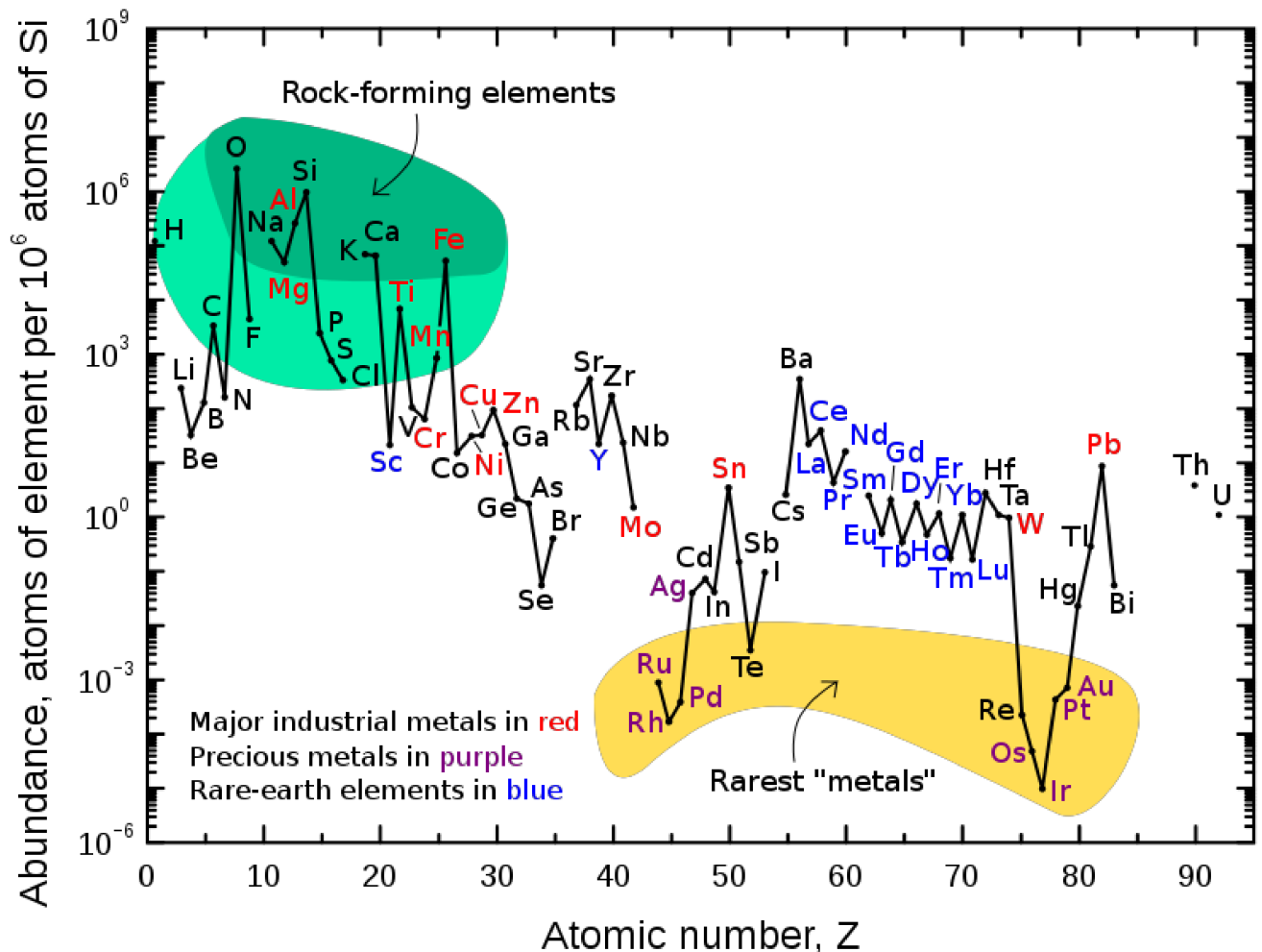

Figure 1. Natural abundance (atom fraction) of the chemical elements in Earth's upper continental crust as a function of atomic number. Source [60].

Currently, more than 200 REE-bearing minerals have been identified [56,61]. Typical existence of REE is in granites, pegmatites, carbonatites, and perovskites [58]. They are usually enriched with phosphate-minerals such as apatite, monazite, bastnaesite, and others [58]. REE minerals are monazite, bastnaesite, loparite, and the lateritic ion-adsorption clays with high grades of LREE, La-Eu, or ceritic earths and xenotime which contains higher grades of heavy rare earth elements, HREE, Gd-Lu or ytter earths [58].

Zhou et al. [54] reported that in the world there are 178 deposits with REE totalling 478 megaton, Mt, as rare earth ores. A survey of 2018 estimates that overall world reserve as metal is $140 \mathrm{Mt}$, of which 55 are in China, 22 in Brazil, 19 in the Commonwealth of Independent States, and $13 \mathrm{Mt}$ in the USA [13]. Thus, China holds $39 \%$ of the overall reserve and produces $100 \mathrm{Kt}$ per year of REE, or $90 \%$ in 2010 [62]. These resources could sustain global REE production for more than a hundred years [54]. Moreover, China developed leading processing technologies and production facilities for REE exploitation.

All REE occur in nature but not in pure metal form. Promethium, the rarest, only occurs in trace quantities in natural materials, as it has no long-lived or stable isotopes [63]. LRE resources are found mainly in monazite minerals in northern China, with the Bayan Obo mine in Inner Mongolia being the world's largest REE mine in operation. HREE resources are enriched in ion adsorption deposits in southern China, where Jiangxi and Guangdong provinces hold almost 70\% of the total deposits [64]. Many processing steps are involved in REE manufacturing, making their separation very complex [65].

\subsection{The Sources of REE Contamination}

There are several REE sources for estuary aquatic environments that can be natural or anthropic. REE can come from rock and soil erosion processes and wind driven transported to open sea [66]. Post-consumer REE products, waste electronic and electrical equipment (WEEE), once reaching the landfills become an incredible source of REE for oceans [67]. Some of these devices, such as computer screens, can contain up to $72 \%$ of Eu in a liquid phase $[2,68]$. Thus, recycling plants for WEEE and other REE-containing wastes such as 
fluorescent lamps, which are common in several countries, including China, India, Pakistan, Nigeria, Ghana, and Vietnam, represent a serious threat [69]. One of the main sources of REE for aquatic systems is the discharge of REE-contaminated wastewater [70], thus representing a great threat for coastal environments via runoff and leaching.

Another important source of REE comes from fertilizers and animals' feeds [31,71,72]. Phosphatic rocks with high loads of REE are often used in the manufacture of phosphate fertilizers and thus may pollute estuaries [3].

\section{Fate of REE in Riverine and Estuary System}

The amount of REE in the fluvial water/sediment system is influenced by the parent materials and organic matter contents, soil texture, paedogenetic processes, and anthropogenic activities [73]. The contraction of the ionic radii of REE leads to systematic changes in the chemical properties along the series with HREE showing a higher propension to form complexes. LREE are preferentially scavenged on particle surfaces, while HREE are retained in dissolved state because of stronger complexation with ligands, $\mathrm{CO}_{3}{ }^{2-}, \mathrm{PO}_{4}{ }^{3-}$, and organic ligands $[17,45,74]$. Sholkovitz [75] reports that the concentration and fractionation of REE in river waters are highly $\mathrm{pH}$ dependent. With increasing $\mathrm{pH}$ fractionation of REE scales occurs in the following order: LREE $>$ MREE $>$ HREE. With decreasing $\mathrm{pH}$ REE are released from particle surfaces in the same order. This means that REE composition in fluvial waters depends much more on water chemistry rather than the rock composition.

REE in river waters are fractionated between colloidal and suspended particles, as oxyhydroxides [76], and solution phases, but it is especially the interaction with the former phases that is responsible for REE transport and distribution [51,52]. Within the dissolved REE, Fe-organic colloids are the major carrier of REE, and this also explains the direct relationship between REE and Fe in rivers and estuaries [77].

A model proposed by Moermond et al. [78] addresses, in riverine waters, the complexation of REE mainly with dissolved organic matter, followed by carbonates and bicarbonates, whereas in seawater the preferential sequence of complexation was carbonates, bicarbonates, and then free ions [78]. This appears mainly driven by $\mathrm{pH}$ increase from 6 to 9 , with a decrease in the free ions and in REE bound to humic ligands, and an increase in REE carbonate and bicarbonate complexes [78]. The abundance of REE in river water, suspended or dissolved, is important to an understanding of their cycling and interaction with seawater as well for knowing their abundances in the continental crust $[79,80]$.

Few studies refer to the distribution of REE in freshwater systems, and most of the existing ones clearly show anthropogenic industrial sources. Emblematic are the cases of $1.5 \mathrm{t}$ of La in the Rhine [81] and the marked increase in Gd by more than 2 orders of magnitude in Berlin, Germany [82], from wastewater treatment plants. In organic-rich rivers, the REE transportation via colloids can cover up to $100 \%$ [83,84]. Generally, the REE in rivers decreases from riverine to brackish to sea water. In fact, mixing processes of fresh with saltwater in estuary zones result in coagulation of colloidal and particulatebound lanthanides and subsequent sedimentation with removal rates in the range of $30 \%$ to $90 \%[51,52,77]$. Once rivers enter the estuary, many physicochemical processes, adsorption, flocculation, diagenetic remobilization, and resuspension occur at the fresh water-sea water interface [76]. Estuaries are important dynamic interfaces linking the continents to the oceans via the transfer of materials from processes of chemical weathering, mechanical soil erosion, and products of biological and anthropogenic activities. REE are often used as tracers of geochemical processes [85-88]. In fact, they are used as tracers of the history of sedimentation by natural processes, such as shoreline erosion and weathering products on the seabed [46] and indicators of sediment provenance [89] and anthropogenic activities [90]. The biogeochemical behaviour of REE in estuarine is influenced by complex hydrodynamics and sediment transport pathways [52,87,88,91-101].

Weathering, erosion and riverine transport, and provenance of sediments and sands have been studied in different estuaries [102]. In estuaries, REE are often normalized to suitable standards, chondrite, shales, and the deviations/anomalies in the abundance of 
one element from the other REE can be quantitatively assessed and then used as water-mass tracers [45], source trackers for suspended particles and groundwater/river discharge [103], and as proxies for redox reactions. REE estuary sediment distribution can also be useful in discriminating the influence of iron oxyhydroxides [104], hydrothermal alterations [105], and volcanoes [106]. Thus, the study of REE contents and shale normalized patterns together with the above-mentioned features could be useful in providing a better geochemical characterization of estuary systems [76].

\subsection{Fractionation}

Even though REE are chemically coherent, in estuary waters they fractionate in relation to biogeochemical processes [70]. The gradual decreasing ionic radius with increasing atomic number and increasing covalence due to progressive infilling of their $4 \mathrm{f}$ electron shell is responsible for fractionation processes [107]. Thus, it is possible to observe low anomalies for $\mathrm{La}, \mathrm{Gd}$, and $\mathrm{Lu}$ due to slight differences between the stabilities of their chemical complexes, and greater anomalies for $\mathrm{Ce}$ and Eu being more redox-sensitive [108].

\subsubsection{Factors Controlling Fractionation of REE}

Distribution, fractionation, fluxes, and composition of dissolved REE in estuary is governed by flushing time, water/particle interactions, solution chemistry, flocculation, organic and inorganic complexation, adsorption, and sediment resuspension, [70]. Diffusion depends on the nature and speciation of REE, geochemical conditions as dissolution and surface complexation reactions with inorganic and/or organic ligands [30]. The abundance and fractionation of dissolved REE depend on certain intrinsic characteristics including salinity, $\mathrm{pH}$, redox potential, dissolved organic matter, mineral phases, and type and concentration of chelating agents [109], flow conditions, microorganism activity, and variations in atmospheric precipitation [110]. A more detailed presentation of the factors influencing REE fractionation is reported in the bioaccumulation section and in the case of La, see Section 3.

The literature reports large-scale release, modification, distribution, and removal of REE in many estuaries of the world [108]. There is an interesting study of Sholkovitz, dating back 1976 [111], that showed that in the low salinity estuarine mixing zone where freshwater mixes with seawater, seawater cations modify the negative surface charges of particles and colloids and facilitate flocculation, impeding REE river flows to reach seawater. The two main processes regulating REE fluxes are salinity-induced coagulation of colloids and adsorption/desorption from the particulate material [112]. The processes of removal, i.e., flocculation, complexation, adsorption, scavenging, and remineralization, occurring in shallow seawater mandate the normalization of REE to standard reference values. LREE and HREE behave differently. In the presence of organic matter and carbonates, LREE are adsorbed by Mn-Fe oxyhydroxides and clay minerals or precipitate as REE phosphates, whereas HREE are more stable if complexed by these ligands [113]. Loads of REE are especially regulated by the composition of the river discharges and the mixing conditions. When $\mathrm{pH}$ is in the acidic range, $\mathrm{REE}$ tend to be dissolved, and when $\mathrm{pH}$ is alkaline precipitate, REE are adsorbed onto clays and hydroxides [114]. Depletion of LREE relative to HREE, negative Ce anomaly and positive La, and Gd natural anomalies are reported [115-117]. Sholkovitz [52] indicated that the balance between coagulation and release from particles determines the net flux and fractionation during estuarine mixing. The author reports that coagulation and preferential removal order of LREE > MREE > HREE are dominant and that it is difficult to identify and quantify the release of dissolved REE in estuaries from suspended particles and sediments as this is a more spatially diffuse process than is coagulation in the low salinity zone. The same Sholkovitz [52] observed REE removal of $97 \%$ in the low salinity mixing zone of the Amazon estuary, whereas under high salinity there is a preferential removal of HREE [118]. A similar removal path was reported by Borrego et al. [114], Andrade et al. [119], and Saha et al. [108], with a fractionation pattern evidencing the enrichment of HLRE and a depletion of HREE relative 
to NASC, North American Shale Composite, the most used reference standard. Thus, REE in seawater are of one or two orders of magnitude lower than river water [77]. For example, Elderfield et al. [77] reported La levels in rivers of 20-600 ng/L and of 5-40 ng/L in estuaries and coastal areas. A more recent paper of Merschel [120] disagree with these data, reporting more conservative behaviour of REE. Some authors have identified dominant factors of speciation and fractionation of REE in estuaries [121], considering total organic carbon, TOC, as the most important factor for speciation and bioavailability of REE in estuary sediments. While $50-60 \%$ of REE was bound to inert complexes and not bioaccessible, about 20-30\% was associated with TOC. In addition, Zhang et al. [122] considered that REE were fractionated as iron and manganese compounds, 8.5-16\%, carbonates, 3-6\%, and water soluble, $1-11 \%$.

\subsubsection{Environmental Application of REE as Tracers of Pollution}

The processes of diagenesis, erosion, weathering, and sedimentation contribute to the REE pollution of estuaries [123]. The level and distribution pattern of REE in water/sediment will help to determine their sources of pollution, either natural and/or anthropogenic. Thus, REE may be useful indicators of anthropogenic inputs. For instance, anomalously high Gd concentrations in waters may indicate contamination with treated wastewater containing hospital effluents [82]. In other cases, it is possible to discriminate mining activities as the case reported by Shynu et al. [124] studying REE distribution in sediments of the Mandovy estuary in India. Authors found that the fine-grained Fe-Mn ore particulates that spilled during transport through the estuary and uploading operations in the port region-controlled estuary REE distribution in the estuary.

Hu et al. [125] studied REE in offshore sediments of Western Xiamen Bay in China and potential sources. The patterns of chondrite-normalized REE exhibited a negative slope, as expressed by LREE/HREE ratios, and enrichment factors, indicating that the REE in surface sediments were from the continental crust and anthropogenic activities such as domestic sewage sludge and coal combustion. The same authors used the ratios $\mathrm{La} / \mathrm{Yb}, \mathrm{La} / \mathrm{Sm}$, $\mathrm{Gd} / \mathrm{Yb}$ to establish some potential sources and reported that REE sediment accumulation in surface sediments might be related to natural sources (parent materials and $\mathrm{Pb}-\mathrm{Zn}$ deposit) and anthropogenic activities (coal combustion and domestic sewage originating from the Marabasco river estuary in the pacific coast of Mexico). This tropical coastal system is rich in iron oxy-hydroxides [126]. Authors found that REE concentrations in the estuary sediments show a strong correlation with $\mathrm{Al}$ and Fe, with LREE having a greater affinity for Fe and HREE for Al. The presence of magnetite and the iron oxy-hydroxide enrichment enhanced this antagonism.

\section{The Bioaccumulation and Bioavailability of REE}

REE can be detected in most of the biota, and the accumulation pattern follows generally the Oddo-Harkin rule [127], with La usually being the second most common lanthanide after cerium (Ce) $[77,127]$.

In estuary aquatic environments, bioaccumulation and bioavailability of REE are strictly linked together. Generally, the more available pool is water soluble and exchangeable [128]. REE bioavailability depends on the REE speciation, which is influenced by physicochemical parameters, $\mathrm{pH}$, alkalinity, and ionic strength and by the presence of different organic and inorganic complexing agents [78]. Although the literature displays some studies on REE distribution and fractionation in estuarine systems, little is known about bioavailability [96].

REE accumulation has been observed in plankton in the Mediterranean Sea [129], algae in China [129], bivalves in Japan and Germany [41], fish in the United States and China [130], and turtles in Sicily [131]. Mayfield and Fairbrother [132] surveyed 10 North American fish species, reporting that REE in freshwater fish muscle ranged from 0.014 to more than $3 \mathrm{mg} / \mathrm{kg}$ dry weight, dw. Another study conducted in China [133] on four species 
of freshwater fish and six species of marine ones highlighted REE means of $35.8 \mathrm{mg} / \mathrm{kg} \mathrm{dw}$ in freshwater fish and $21.0 \mathrm{mg} / \mathrm{kg} \mathrm{dw}$ in marine fish.

The specific characteristics of organisms and aqueous phase play a paramount role for bioaccumulation. LREE have been found to accumulate in higher amounts in fish, daphnia, duckweed, and shellfish, as well as in phytoplankton [134].

Specific cases of bioaccumulation was found with regard to La as in the whole soft parts of scallop Chlamys varia [135], 0.12-2.96 $\mathrm{\mu g} / \mathrm{g}$ dry wt basis; the amphipod Paramoera walker, 0.10-0.17 $\mu \mathrm{g} / \mathrm{g}$ dry wt basis [136]; blue mussels Mytilus edulis, $1.141 \mu \mathrm{g} / \mathrm{g}$ dry wt basis [137]; the snails (Potamopyrgus antipodarum; Lymnaea stagnalis; Radix ovata; Physella acuta; Planorbarius corneus; Planorbis planorbis); and bivalves (Dreissena polymorpha; Corbicula fluminae) [127]. In another recent report, Nørregaard et al. [138] showed a REE accumulation in liver, gill, and muscles of Salvelinus alpinu, typical of arctic and subarctic coastal waters, after exposure to $\mathrm{Ce}, \mathrm{La}$, and $\mathrm{Y}$.

Ma et al. [139] studied REE in the Pearl River Delta of China and found enhanced accumulation of LREE in oyster from suspended particles, due to recycling and different industrialized activities. Jiao et al. [140] assayed the levels of REE in the mantis shrimp Oratosquilla oratoria collected from Shandong Province, China. The calculation of estimated daily intake (EDI), target hazard quotient (THQ), and total target hazard quotient (TTHQ) showed that REE were below harmful limits.

Many bioaccumulation trials fail to reproduce real conditions found in the field, matrices, and concentrations. An alternative procedure for studying REE exposure of aquatic organisms is the use of the diffusive gradient in thin-films, DGT, which provides reliable and sensitive in situ measurements of DGT-labile metal species [141]. However, the effectiveness of the DGT approach is often questioned for measuring REE in estuarine waters. This is the case of the study of Cánovas et al. [142] reporting on the REE availability in the estuarine waters of the Ría of Huelva, SW Spain, strongly affected by mining activities. Authors considered the ability of REE to cross the biological membranes and related metal lability to the concentration of REE in the water column. The ineffectiveness of the DGT to measure bioavailability was attributed to the instability of complexes in contact with the DGT membranes and the inability of metals to form thermodynamically stable complexes of the absorption with colloids.

\subsection{Fish Species as Bioindicator of REE Pollution}

Some authors [130] evaluated the possibility of using European eels, Anguilla anguilla, as an indicator of estuary REE. Bioaccumulation of REE in this fish is rather significant, being a benthic species living in contact with the sediment and at the top of the trophic chain of estuarine [143,144]. Later, Lortholarie et al. [37] studied REE bioaccumulation in the yellow and silver European eel, Anguilla, in the Loire estuary, characterized by a large anthropogenic pressure. The results showed that males accumulated more REE than females and that silver eels accumulated more REE than yellow ones. Authors observed an increase in the temporal REE accumulation for silver eel muscles related to the increase in REE uses. More recently, the same authors, [145] studied REE organotropism in the same species and estuary. They observed differences were between life stages and genders, with most accumulating organs being gills and liver. REE distribution was also different between genders. The gonads of female silver eels showed a specific profile with greater presence of $\mathrm{Gd}$, up to $74.2 \%$ of REE with respect to male. Other example of tropism is reported by Pernice et al. [146] who determined preferential accumulation of La in digestive glands of two nautilus species with similar physiology but from different geographic areas. Purpleback flying squid Sthenoteuthis oualaniensis collected in the IndoPacific Ocean demonstrated age-dependent differences in accumulation in certain tissues, such as liver [147]. The liver of adult squids possessed significantly lower La concentrations than that of juveniles. The same pattern occurred for other lanthanides and some essential elements. Squids represent a high trophic level in the marine food web; thus, in addition to seawater, diet may contribute to accumulation. Therefore, it was assumed, that changing 
food sources during the life span of S. oualaniensis was responsible for the variations between stages. However, the same authors found higher La in the stomach content of adults. Chassard-Bouchard and Hallegot [148] also studied the fate of La after uptake by molluscs and found that the element, adsorbed via the gills or the digestive gland, undergoes detoxification through adsorption to insoluble fractions within the cells of the digestive gland, accumulating as insoluble lanthanum-phosphate in organelles. Bustamante and Miramand [135] studied the tissue concentration and partitioning of $\mathrm{La}, \mathrm{Nd}$, and $\mathrm{Ce}$ among in variegated scallop Chlamys varia from an unpolluted and a polluted location in the Atlantic Ocean near the French coast. Authors found that animal tissues from the polluted site showed higher concentrations of lanthanides. Digestive glands followed by gonads and gills showed the highest uptake of REE. Lowest La concentrations occurred in muscle. High lanthanide concentration in gills was related to direct seawater exposure, compared with gonads, where transport from the intestine via food particles occurred.

Sometimes the length of the shell is an indicator of REE accumulation, as shown by Riget et al. [137] who related elemental concentration and length of the shell of the blue mussels, Mytilus edulis, from four unpolluted sites in the West Greenland fjord. Authors found a lanthanum level increase of about $100 \%$, while shell length was doubled.

Another bioindicator of REE is reported to be the fiddler crab, Leptuca leptodactyla [149]. The authors used the crab to verify the presence of REE in two mangrove areas of the Ubatuba, northern littoral of São Paulo state, Brazil, and revealed the presence of REE, especially $\mathrm{La}$ and $\mathrm{Ce}$, with a correlation with city sewage anthropic flows. Fiddler crabs have direct relation with the mangrove sediments being deposit feeders, and bioturbators [150]. Another high-REE-accumulating marine species is the mantis shrimp Oratosquilla oratoria, widely distributed in the coastal waters of China. Ng et al. [151] found LREE accumulation in this shrimp to be 10 times higher compared with HREE. Authors such as Bonnail et al. [152] consider using the high REE accumulation capacity of bivalves to survey acid mine drainage pollution, similar to the approaches used by metal pollution monitoring programs [153].

\subsection{Mechanisms of Bioavailability}

Here we report the case of the free ion, $\mathrm{La}^{3+}$, the most bioavailable lanthanum species, followed by hydroxides [78]. Molecular or ionic mimicry have been suggested as processes that enable uptake of non-essential, cationic metal species across membranes [154]. $\mathrm{La}^{3+}$, for example, resembles calcium ions for ionic binding capacity and dimension. The high charge to volume ratio of $\mathrm{La}^{3+}$ increases its chances to bind on protein sites, where it can replace $\mathrm{Ca}^{2+}, \mathrm{Mg}^{2+}, \mathrm{Fe}^{3+}$, and $\mathrm{Mn}^{2+}$ [155]. The open question is whether $\mathrm{La}^{3+}$ can cross cellular membranes. Some authors [155] report that the $\mathrm{La}^{3+}$ displacing $\mathrm{Ca}^{2+}$ from the cell membrane hampers Ca-dependent functions. However later studies of Wang et al. [156,157] demonstrated $\mathrm{La}^{3+}$ uptake into the cell. A former study of Palasz and Czekaj [158] speculated that the REE could be internalized through a Ca channel. Due to the existing research gap, bioaccumulation in marine primary producers occurs according to paths borrowed from those of terrestrial plants: bioaccumulation occurs in parallel with the increased activity of the enzyme glutamic oxaloacetic transaminase, GOT [134].

\subsection{Factors Influencing Bioavailability}

The bioavailability of La depends on many different factors, such as the water hardness, $\mathrm{Ca}^{2+}, \mathrm{Mg}^{2+}$, alkalinity, $\mathrm{HCO}_{3}{ }^{-}, \mathrm{CO}_{3}{ }^{2-}, \mathrm{pH}$, and dissolved organic carbon, DOC. All these features modify the activity of the bioavailable species and ultimately modify the interaction with the organism membranes. As already stated before, the richness of $\mathrm{HCO}_{3}{ }^{-}$and $\mathrm{CO}_{3}{ }^{2-}$ decreases the bioavailability of REE $[78,159,160]$. This could be attributed to increased competition for Ca-binding sites on the proteins of the membrane or to formation of biologically unavailable La-carbonates causing a decrease in the potential bioavailable forms, $\mathrm{La}^{3+}$ and $\mathrm{LaOH}^{2+}$ [78]. This might implicate the modulation of the environmental quality criteria with the water hardness, like that already elaborated for cadmium [161]. 
Bioavailability of $\mathrm{La}$ in aqueous systems is influenced by complexation with the dissolved organic matter, the presence of competitive cations, and $\mathrm{pH}$ [83]. Mechanistic studies based on mean DOC concentration of world fluvial waters of $5 \mathrm{mg} / \mathrm{L}$ reported $\mathrm{La}^{3+}$ complexed with sulfate at $\mathrm{pH} 5.4$ and carbonate at $\mathrm{pH} 7.9$ [83]. At neutral $\mathrm{pH}$, $\mathrm{La}^{3+}$ complexes with soluble organic matter even though the authors do not exclude the competing role of $\mathrm{Fe}, \mathrm{Al}$, and of carbonate ions, especially for light molecular weight DOC at neutral to alkaline $\mathrm{pH}$ [162].

Zhao and Wilkinson [163] studied the bioavailability of seven REE for the freshwater alga Chlamydomonas reinhardtii in the presence of organic ligands. On the base of the biotic ligand model, BLM, the authors initially hypothesized that complexation would reduce bioaccumulation in direct proportion to the concentration of the free ion. The results of the study evidenced that the uptake of REE was much higher than that predicted by the BLM. In the case of Thulium, Tm, the enhanced uptake was attributed to the formation of a ternary complex among the ligand, Tm, and the metal transport site on the cell membrane. As organic ligands are ubiquitous in natural waters, it is likely that REE will be in complexed form and that simple models will underestimate REE bioavailability. Thus, it is crucial to have a deep knowledge of REE speciation to predict their bioavailability, especially in natural waters where the stability constants of REE with the organic matter are poorly known [163].

In general, the literature reports that the bioaccumulation of REE in the marine environment has a limited chance for biomagnification and often undergoes trophic dilution [36,152,164]. However, a contrasting result is reported by Reindl and Falkowska [165], who found the dominant presence of HREE in the muscles of key clupeid from Gdansk Bay, South Baltic Sea, and Iberian Peninsula, Northeast Atlantic. REE also accumulate in the ova and seminal fluid, highlighting intergenerational transfer, meaning the accumulation and biomagnification potential of REE in the trophic chain [165]. Souza et al. [37] studied the trophic transfer in a neotropical mangrove ecosystem food web. The authors discovered significant evidence of biomagnification along the levels, plankton, oyster, shrimp, crabs, and fish for some REE and for others a bio-dilution, depending likely to different pollution degrees, according to Souza et al. [37]. The study also found that Ce, La, and Y inputs were linked to solid waste from steel factories and that $\mathrm{Nb}$ was linked to atmospheric particulate.

\section{The Toxicity of REE}

In general, the eco-toxicological behaviour of REE resembles that of non-essential metals, with lower effects at low concentrations, whereas at higher concentration, toxicity increases [166]. There are reports highlighting the toxicity of La because of its bioaccumulation in the brain and nervous system of marine organisms [167]. Knowledge on the toxicological mechanisms of REE in marine systems is deficient and most of the literature refers to LREE, mainly La and Ce [71,72]. Among marine taxa, crustaceans (invertebrates) are the taxonomic group with the largest number of studies and show the highest sensitivity towards La. Studies on Daphnia carinata [159] in three media of different composition and water hardness reported a strong relation between La toxicity and water hardness and total Ca content, as well as medium composition. Water hardness modifies the toxicity, as $\mathrm{La}^{3+}$ competes with $\mathrm{Ca}^{2+}$ for binding sites in biological systems [155] and leads to increasing mortality with decreasing water hardness. Mechanisms of toxicity can be borrowed from plants. Carpenter et al. [168] report how REE may interfere with the uptake of Ca in plants having similar ionic radii, inhibiting root growth, cell wall integrity, photosynthesis, and flowering. Elevated levels of La, Ce, and $\mathrm{Pr},>50 \mathrm{mg} / \mathrm{L}$, may inhibit photosynthesis [169]. REE may interfere with biogeochemical cycling and macrofaunal diversity [170]. Thus, La and $\mathrm{Ce}$ are often chosen as REE models in toxicity determinations because of their wide use and high abundancy with respect to other REE in the environment [171]. For these reasons $\mathrm{La}$ and $\mathrm{Ce}$ are more investigated, and more thermodynamic data are available for chemical speciation calculations [172]. Impairments in sea urchins' larval development, morphological changes in tentacles of cnidarians, physiological changes and oxidative 
stress in mussels, loss of growth and reproduction in microcrustacean water flea, and physiological impairment in the European eel are reported [130,173-177].

REE influence main biological processes, embryogenesis, fertilization, cytogenetic, and redox endpoints. Cytotoxic inhibition of mitotic activity, mitotic aberration, and micronuclei introduction were observed in Paracentrotus lividus and Arbacia lixula sea urchins [71,72]. They can alter the functions of calcium due to similarity in size and affinity for phosphate groups of macromolecules [176]. Redox imbalance leading to oxidative stress, OS, lipid peroxidation, and modulation of antioxidant activities are reported for La and Ce [178-180]. Hongyan et al. [181] reported induced changes in enzymatic activities after exposure of the Cyprinid Carassius auratus to REE. Oral et al. [182] detected excess of mitotic aberrations in sea urchin embryos and gametes. González et al. [183], in a survey with different species, bacteria, algae, crustaceans, rotifer, and cnidarians, concluded that the REE toxicity is dependent on organisms and increases with the atomic number. In a study on rare minnow, Gobiocypris rarus, Hua et al. [184] evidenced that La severely caused gills desquamation and necrosis and liver histopathological changes. Significant variations in gill dimensions and metabolic disturbance were observed. The toxicity of La and $\mathrm{Y}$ on the developing embryos and juveniles of marine mussel Mytilus galloprovincialis was studied by Mestre et al. [185]. Authors reported a greater toxicological effect onto developing embryos and larvae than juveniles. The study also set up the predicted no effect concentration, PNEC, as a first step toward deriving environmental quality criteria and for assessing the environmental risk. PNEC defines the maximum concentration allowed at which the ecosystem is protected [186].

Consideration of metal speciation during exposure is essential for improving our understanding of metal toxicity to aquatic organisms [187]. Studies of Aharchaou et al. [188] related the toxicity of $\mathrm{La}$ and $\mathrm{Ce}$ to metal speciation in solution and demonstrated that the calculated free ion concentration was a good indicator of toxicity. Increasing the ambient calcium concentration protected the test algae by reducing the amount of lanthanide internalized into the cells. The results suggested that, at constant $\mathrm{pH} 5.5$, REE accumulation and toxicity are linked to the free ion concentration and ambient calcium concentration, as predicted by the biotic ligand model.

The assessment of REE toxicity is also hampered by the chemical nature of REE, which are almost insoluble at neutral $\mathrm{pH}$, of phosphates, which are ubiquitous in algal growth media, and carbonates at high $\mathrm{pH}$ [189]. REE precipitation has been seen in many artificial laboratory studies and test media [159,190,191]. El-Akl et al. [189] bypassed the issue using an alga such as Chlorella fusca, which is capable of growing with low phosphate medium. Another major problem for toxicity assessment comes from the scant demonstrated capacity of the biotic ligand model, BLM, normally used for bivalent metals [192] to explain trivalent REE bioavailability in the presence of different organic ligands [183]. In light of these considerations, González et al. [183] hypothesized that the toxicity and risk of REE in the absence of phosphates would be significantly higher than that shown in the literature [183]. Other authors consider that La and Ce might have similar toxicity features due to the similarity of their physicochemical properties [193]. This wide limitation of data leads some authors to base their REE prediction of toxicity on free cation concentrations, attributing a protective role to Ca [194,195].

As stated above, the limited amount of data in the literature means that it is very difficult to establish threshold limits of REE for water and sediments. Herrmann et al. [171] studied the aquatic ecotoxicity of La, considered as the major lanthanides in industrial effluents, to draw such quality criteria. The only quality criteria for the freshwater community were defined due to poor availability of tests with marine organisms.

$\mathrm{Nd}$ is an element largely applied in high-tech processes [196], with a high potential to be released into coastal areas from e-waste disposal (50 million tons in 2018) and mining activities, the main source of REE into waters [34]. Its mean concentration in groundwater, depending on climate, geology, vegetation, and oxidation state, is in the range 3.1-146.2 $\mathrm{mg} / \mathrm{L}$, at various sites worldwide [34]. In sea water, $\mathrm{Nd}$ concentrations 
are significantly lower: $2.8 \mathrm{ng} / \mathrm{L}$ [197] due to higher $\mathrm{pH}$ and sediment accumulation by dissolution and surface complexation reactions with inorganic and organic ligands [9]. However, some areas, such as coastal areas of Hawaii, Kona, and Australia, Labrador beach, revealed concentrations of $\mathrm{Nd}$ in seawater of $24-32 \mathrm{mg} / \mathrm{L} \mathrm{[34].} \mathrm{The} \mathrm{increasing}$ presence of $\mathrm{Nd}$ in oceans and potential bioaccumulation is supported by a very limited toxicological literature. Only recently, Freitas et al. [177] demonstrated the accumulation of $\mathrm{Nd}$ and the biochemical alterations in the mussel Mytilus galloprovincialis. The authors exposed the mussel to five different concentrations, $2.5-40 \mu \mathrm{g} / \mathrm{L}$ for 28 days. A metabolic capacity increase and glycogen content (GLY) expenditure were recorded with insufficient elimination of ROS, highlighting cellular damage and compromission on mussel's survival, growth, and reproduction [177]. These data come from laboratory assays and do not faithfully reproduce real field conditions in terms of concentration and duration of exposure. Another growing ecotoxicological concern regards $\mathrm{Tb}$, used in newly developed electronic devices. Mean concentration for $\mathrm{Tb}$ of $1.16 \mathrm{mg} / \mathrm{kg}$ up to a maximum value of $2.6 \mathrm{mg} / \mathrm{kg}$ was measured in downstream Lubumbashi River in the Democratic Republic of the Congo sediments [198]. A recent contribution comes from Lompré et al. [199], who reported metabolic impairment, loss of redox balance, and neurotoxicity in clams, either native Ruditapes decussatus or invasive Ruditapes philippinarum species, exposed to $\mathrm{Tb}$. $\mathrm{Tb}$, was reported to have effects on physiological features, affecting reproduction and growth capacities. Authors in their exposure experiments adopted a level of Tb of $50 \mu \mathrm{g} / \mathrm{L}$.

Gadolinium has been found very often in freshwater environments, with levels of 0.347 to $80 \mu \mathrm{g} / \mathrm{L}$, with more significant anomalies nearby industrialized areas and bioaccumulation range of 0.006 to $0.223 \mu \mathrm{g} / \mathrm{g}$ with variability due to the $\mathrm{Gd}$ complexes' chemical speciation [62]. As the free ion $\mathrm{Gd}^{3+}$ is toxic, contrast agents correspond to inert chemical complex-for example, Gd-DTPA (Gd chelates of the open-chain diethylenetriaminepentaacetic acid). Its high stability allows a complete excretion by the human organism only a few hours after the examination [62]. These Gd complexes are released into the hydrosphere through the effluent of sewage plants. Gadolinium is a very threating pollutant for aquatic systems, behaving conservatively since it is rarely removed in wastewater treatment plants [200]. A study of Möller et al. [201] reports that Gd complexes are stable and pass through wastewater systems almost unchanged, showing that it is neither adsorbed not co-precipitated, nor does it undergo ion exchange with organic or inorganic particulate sewage matter. Other studies report on the conservative behaviour of anthropogenic complexes of Gd [202]. Some authors as Telgmann et al. [203] report on the trans-metallation with endogenous ions of $\mathrm{Fe}^{3+}, \mathrm{Zn}^{2+}$, and $\mathrm{Cu}^{2+}$ as being responsible for the release of toxic $\mathrm{Gd}^{3+}$ ions. Anomalous levels of $\mathrm{Gd}$ in the aquatic environment, mostly freshwater, are reported: [204-207]. In the water column of low salinity zones of estuaries, Gd associates with organic and mineral colloidal ligands and scantly fluxes to pelagic waters [206,208]. Thus, in the estuarine mixing area, anthropogenic $\mathrm{Gd}$ is not particle reactive since anionic $\mathrm{Gd}$ complexes have a long environmental half-life [209] partitioning from the truly dissolved REE pool [209]. Consequently, anthropogenic Gd may be decoupled from the natural REE and may serve as a conservative tracer of soluble wastewater-derived substances to estuarine and coastal waters [207,210].

The toxicity of Gd and its long-term lability are still poorly known [211,212], and its levels have shown a significant increase over short periods of time in some locations [207]. The effects of $\mathrm{Gd}$ in invertebrate marine species include alterations of gene expression, cellular homeostasis, shell formation, metabolic capacity, and antioxidant mechanisms [62]. Specifically, for sea-urchin species, Paracentrotus lividus and Heliocidaris tuberculate, inhibition on skeleton growth, changes in the biomineralization process, and induction of autophagy have been shown $[213,214]$. With respect to $\mathrm{Gd}$, whose levels in sea water are difficult to detect due to its high reactivity, natural La is highly variable and in the range of 20-600, 5-200, and 5-40 ng/L in rivers, estuaries, and coastal areas, respectively [77]. Some authors observed anthropic La release from fluid catalytic cracking catalysts [215,216] or acid mine drainage $[216,217]$ that produce significant enrichment up to $0.04 \mathrm{mg} / \mathrm{L}$, as in a 
Spanish aquifer contaminated by acid mine drainage [217] or even higher $0.9 \mathrm{mg} / \mathrm{L}$ in streams flowing near acid sulphate soils [218]. Although $\mathrm{La}^{3+}$ is a very small fraction of the lanthanum compounds in water and sediment, in this soluble ionic form it has great biological effects [219].

The La cytotoxicity is attributed to the chemical similarity relative to alkaline earth elements through the competition for binding sites with Ca [219]. La acts by damaging Ca-channels of membranes, altering membrane enzyme activities, and influencing tissues components [219]. Gills and liver necrosis were reported by Hua et al. [184] in the freshwater Cyprinidae Gobiocypris rarus exposed to La. Early studies of Das et al. [218] report several cases of $\mathrm{La}^{3+}$ toxicity to marine fishes, particularly on nervous systems, excretory organs, and smooth muscles. Pinto et al. [220] reported oxidative stress and neurotoxicity and histopathological impacts in gonads, gills, and digestive glands of Mytilus galloprovincialis exposed to La. Neurotoxicity, marked increase in acetylcholinesterase, AChE, activity, was also reported by Figueiredo et al. [130] in a La exposure experiment of glass eels; neurotoxicity was attributed to inhibition of AChE binding [138]. A similar effect was also described years back by Tomlinson et al. [221] in electric eel, Electrophorus electricus, with La affecting the kinetics of acetylcholinesterase.

Some other studies refer to the beneficial effects of $\mathrm{La}^{3+}$ in relation to toxicity of heavy metals: Hong et al. [222] reported the $\mathrm{La}^{3+}$ mitigation of destruction of intestinal DNA caused by $\mathrm{Hg}^{2+}$ and decrease in gill $\mathrm{Cd}$ uptake in epithelial cells from Oncorhynchus mykiss [223]. Results were often contrasting, depending on organism sensitivities, with early life stages being the most sensitive, according to Block and Pärt [224].

\subsection{The Hormetic Effect and the Weight of $p H$}

Many contrasts come out when assaying the ecological risk assessment of REE [172]. A biphasic hormetic effect is described for REE in freshwater or marine environment. Wang et al. [225] evaluated the effect of $\mathrm{Nd}$ on the growth and biochemical changes in the freshwater cyanobacteria Microcystis aeruginosa. A stimulating effect was observed at levels $\leq 1 \mathrm{mg} / \mathrm{L}$ and an inhibitory one at higher concentrations of $5.00-10.00 \mathrm{mg} / \mathrm{L}$. Hormetic REE effects were also reported by Wang et al. [226] and Jenkins et al. [227], but the literature is so limited that it does not help to clarify the weight of hormesis [71,72].

Another unknown role on the REE health effect is $\mathrm{pH}$ dependent REE speciation and hence toxicity. Estuaries can receive industrial effluents from mining areas with a combination of the REE by products and acidity pollution. From the limited available literature, it seems that the acidification of the estuaries enhances REE toxicity [71,72].

\subsection{REE Detoxification Routes}

One possible route of REE detoxification is represented by the already described REE bioaccumulation, see previous section on the trophodynamics, of a large reserve of REE in the digestive glands of fish species, such as scallops, on a subcellular level in organelles, membranes, or granules of the digestive system, as insoluble fractions. Another route could be represented by the REE bio-dilution process along the food web, as outlined by studies of Campbell et al. [228] on trophodynamics of metals in the Artic marine food web. The authors found that La concentrated at high levels in algae and zooplankton with respect to accumulation in fish, seals, and birds. Authors concluded that these elements could be easily bioconcentrated from seawater by pelagic plankton, with limited trophic transference [228].

\section{Reducing REE Fluxes}

Different solutions can be proposed to reduce the input of REE in the environment and specifically in estuary systems, but most of them are not feasible in the medium term [229], and they are expensive, difficult, and complex [230]. Practical examples regard production of items, such as magnet and power generators requiring low levels of REE or of devices with a longer life as is the case and of wind turbines living more than 10 years [231]. Other 
options are the optimization of ore extraction technologies [62], the promotion of e-waste recycling, from spent magnets, catalysts, and cellular phones, Figure 2 [2,232]. Often recovery rates are very low, $<0.1 \%$ as for phones [233]. Often, e-waste recycling is limited to the laboratory level [2], and standard methods for REE recycling are missing [234]. Another option is trans materialization; as for example, the substitution of $\mathrm{Dy}$ in $\mathrm{Nd}$, $\mathrm{Dy}-\mathrm{Fe}-\mathrm{B}$ magnets with Ga-doped sintered $\mathrm{Nd}-\mathrm{Fe}-\mathrm{B}$ magnets [235]. Another example is to use iron borides for hydrogen generation as alternative catalysts [236]. Our thought is that the proposed solutions represent only a weak example of an attempt to contain the increasing release of REE in the environment as with other emerging contaminants. Some of these solutions appear rather impractical since reducing REE load in high tech devices seems unrealistic but perhaps other ideas such as trans materialization and e-waste recycling seem more feasible.

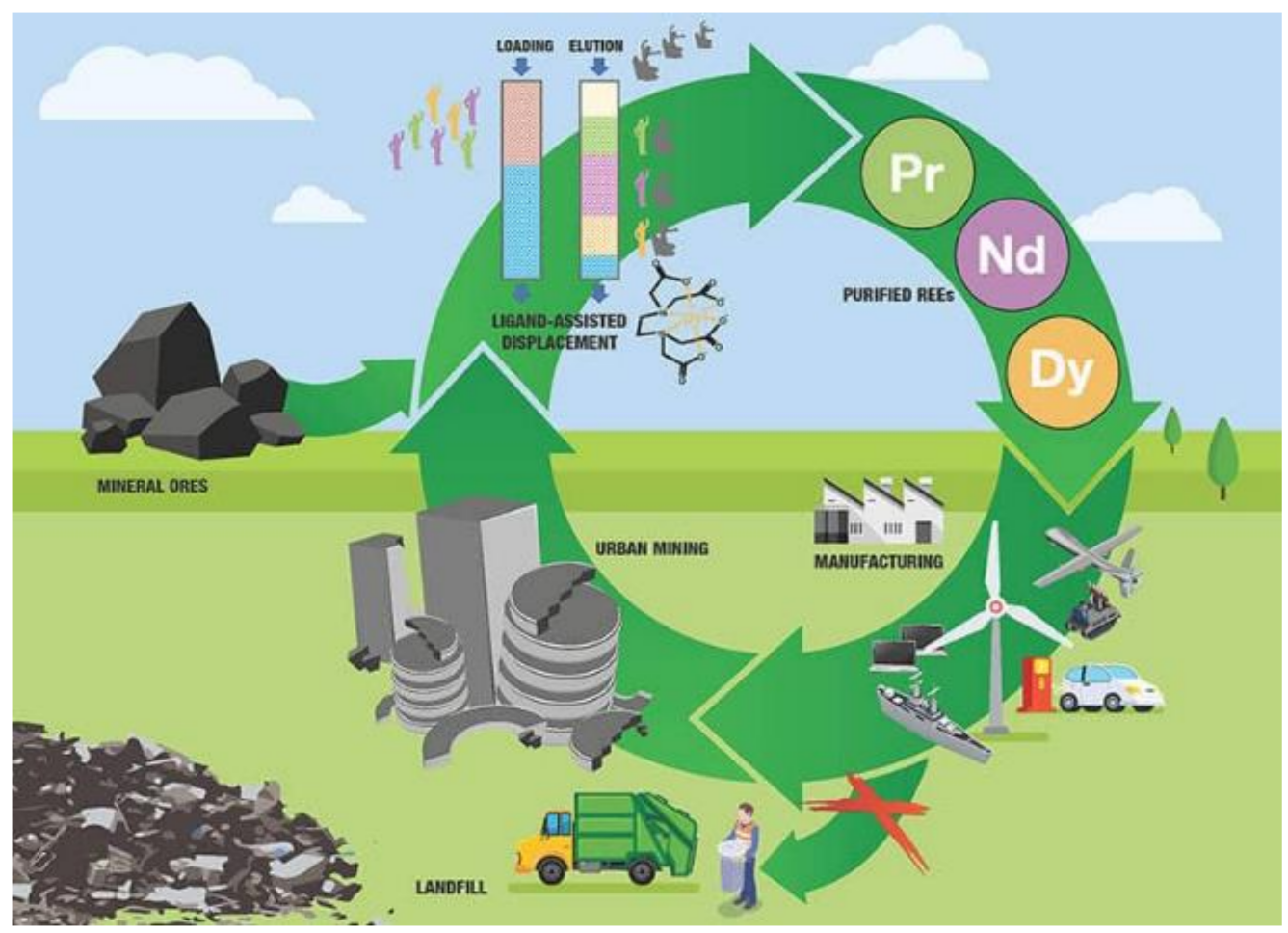

Figure 2. Example of strategic recycling pathway of REE. Source: Source [236].

\section{Conclusions}

The extensive utilization of REE in day-to-day life urges a deep knowledge of the environmental behaviour of these elements in estuarine and coastal mixing zones to strengthen our understanding of REE geochemistry at the continent-ocean interface. These transition environments are complex systems, comprising different biological systems, plants, fish, zooplankton, and algae that interact with REE in different ways and where REE behaviour and fate is in its infancy state and many knowledge gaps exist. Limited is knowledge of the process of ion exchange, sorption-desorption, and precipitation, as well as knowledge of the persistence, transport, and phase partitioning and interactions of REE with sediment and suspended matter.

There is need for further studies on REE mechanisms of biological uptake, bioaccumulation, and toxicity by aquatic organisms. Most studies focused on the prevalence and concentration of $\mathrm{Gd}, \mathrm{La}$, and $\mathrm{Ce}$, and hence, the environmental monitoring and characterization studies must be extended to other REE. New ecotoxicological assays must be performed on different species spanning different ecological levels, from the molecular level to the population level to the ecosystem level and even on to ecosystem services. This 
will be fundamental for determining acute and chronic ecotoxicity and for performing accurate risk assessment analyses of REE in estuary and coastal environments.

Author Contributions: Writing-original draft preparation, conceptualization, data curation, M.A.; writing—review and editing, L.F.; writing—review and editing, M.T. (Marco Trifuoggi); writingreview and editing, M.T. (Maria Toscanesi). All authors have read and agreed to the published version of the manuscript.

Funding: This research received no external funding.

Institutional Review Board Statement: Not applicable.

Informed Consent Statement: Not applicable.

Data Availability Statement: Not applicable.

Conflicts of Interest: The authors declare no conflict of interest.

\section{References}

1. Klinger, J.M. A historical geography of rare earth elements: From discovery to the atomic age. Extrac. Ind. Soc. 2015, 2, 572-580. [CrossRef]

2. Tan, Q.; Li, J.; Zeng, X. Rare earth elements recovery from waste fluorescent lamps: A review. Crit. Rev. Environ. Sci. Technol. 2015, 457, 749-776. [CrossRef]

3. Ramos, S.J.; Dinali, G.S.; Oliveira, C.; Martins, G.C.; Moreira, C.G.; Siqueira, J.O.; Guilherme, L.R.G. Rare earth elements in the soil environment. Curr. Pollut. Rep. 2016, 21, 28-50. [CrossRef]

4. Huang, C.H. Rare Earth Coordination Chemistry: Fundamentals and Applications; John Wiley \& Sons: Singapore, $2010 ;$ p. 592.

5. Wood, S.A. The aqueous geochemistry of the rare-earth elements and yttrium: 1. Review of available low-temperature data for inorganic complexes and the inorganic REE speciation of natural waters. Chem. Geol. 1990, 82, 159-186. [CrossRef]

6. Sneller, F.E.; Kalf, D.; Weltje, L.; Van Wezel, A. Maximum Permissible Concentrations and Negligible Concentrations for Rare Earth Elements (REEs); Report 601; Rivm: Bilthoven, The Netherlands, 2000; p. 66.

7. Nockemann, P.; Thijs, B.; Postelmans, N.; Van Hecke, K.; Van Meervelt, L.; Binnemans, K. Anionic rare-earth thiocyanate complexes as building blocks for low-melting metal-containing ionic liquids. J. Am. Chem. Soc. 2006, 128, 13658-13659. [CrossRef] [PubMed]

8. IUPAC. Nomenclature of Inorganic Chemistry. IUPAC Recommendations, 2005 ("Red Book"); RSC Publishing: Cambridge, UK, 2005; p. 366.

9. Gwenzi, W.; Mangori, L.; Danha, C.; Chaukura, N.; Dunjana, N.; Sanganyado, E. Sources, behaviour, and environmental and human health risks of high-technology rare earth elements as emerging contaminants. Sci. Total Environ. 2018, 636, 299-313. [CrossRef] [PubMed]

10. Bru, K.; Christmann, P.; Labbé, J.F.; Lefebvre, G. Panorama 2014 du Marché des Terres Rares; BRGM/RP-65330; Cedex: Orleans, France, 2015.

11. Atwood, D.A. The Rare Earth Elements. Fundamentals and Applications; John Wiley \& Sons: West Sussex, UK, $2012 ;$ p. 624.

12. Australian Industry Commission. New and Advanced Materials; Australian Government Publishing Service: Melbourne, Australia, 1995; p. 401.

13. U.S. Geological Survey. Minerals Yearbook-Rare Earths. Available online: https://minerals.usgs.gov/minerals/pubs/ commodity/rare_earths/mcs-2015-raree.pdf (accessed on 28 October 2021).

14. International Union for Pure and Applied Chemistry (IUPAC). Nomenclature of Inorganic Chemistry: IUPAC Recommendations 2005. IUPAC Red Book; RSC Publishing: London, UK, 2005; ISBN 0-85404-438-8.

15. de Baar, H.J.W.; German, C.R.; Elderfield, H.; van Gaans, P. Rare earth element distributions in anoxic waters of the Cariaco Trench. Geochem. Cosmochim. Acta 1988, 52, 1203-1219. [CrossRef]

16. Elderfield, H.; Greaves, M.J. The rare earth elements in seawater. Nature 1982, 296, 214-219. [CrossRef]

17. Deng, Y.; Ren, J.; Guo, Q.; Cao, J.; Wang, H.; Liu, C. Rare earth element geochemistry characteristics of seawater and porewater from deep sea in western Pacific. Sci. Rep. 2017, 7, 16539. [CrossRef]

18. Massari, S.; Ruberti, M. Rare earth elements as critical raw materials: Focus on international markets and future strategies. Res. Policy 2013, 381, 36-43. [CrossRef]

19. Metalpedia. Available online: http://metalpedia.asianmetal.com/metal/rare_earth/application.shtml (accessed on 15 November 2021).

20. Li, C.R.; Zhuang, Z.Y.; Huang, F.; Wu, Z.C.; Hong, Y.P.; Lin, Z. Recycling rare earth elements from industrial wastewater with flowerlike nano- $\mathrm{Mg}(\mathrm{OH})_{2}$. ACS Appl. Mater. Interf. 2013, 5, 9719-9725. [CrossRef] [PubMed]

21. Li, X.; Chen, Z.; Chen, Z.; Zhang, Y. A human health risk assessment of rare earth elements in soil and vegetables from a mining area in Fujian Province, Southeast China. Chemosphere 2013, 93, 1240-1246. [CrossRef] [PubMed]

22. Paulick, H.; Machacek, E. The global rare earth element exploration boom: An analysis of resources outside of China and discussion of development perspectives. Resour. Policy 2017, 52, 134-153. [CrossRef] 
23. Tepe, N.; Romero, M.; Bau, M. High-technology metals as emerging contaminants: Strong increase of anthropogenic gadolinium levels in tap water of Berlin, Germany, from 2009 to 2012. Appl. Geochem. 2014, 45, 191-197. [CrossRef]

24. Zhang, Y.; Gao, X. Rare earth elements in surface sediments of a marine coast under heavy anthropogenic influence: The Bohai Bay, China. Estuar. Coast. Shelf Sci. 2015, 164, 86-93. [CrossRef]

25. Anastopoulos, I.; Bhatnagar, A.; Lima, E.C. Adsorption of rare earth metals: A review of recent literature. J. Mol. Liq. 2016, 221, 954-962. [CrossRef]

26. Zhou, B.; Li, Z.; Zhao, Y.; Zhang, C.; Wei, Y. Rare earth elements supply vs. clean energy technologies: New problems to solve Gospod. Surowcami Miner. 2016, 32, 29-44. [CrossRef]

27. Alonso, E.; Sherman, A.M.; Wallington, T.J.; Everson, M.P.; Field, F.R.; Roth, R.; Kirchain, R.E. Evaluating rare earth element availability: A case with revolutionary demand from clean technologies. Environ. Sci. Technol. 2012, 46, 3406-3414. [CrossRef]

28. Qu, K.M.; Xin, F.Y. Enhancement effects of three rare earth elements on the growth of Chaetoeeros mulleri. Mar. Sci. Bull. 2001, 3, 83-88.

29. Cai, L.; Park, Y.S.; Seong, S.I.; Yoo, S.W.; Kim, I.H. Effects of rare earth elements-enriched yeast on growth performance, nutrient digestibility, meat quality, relative organ weight and excreta microflora in broiler chickens. Livest. Sci. 2015, 172, 43-49. [CrossRef]

30. Migaszewski, Z.M.; Galuszka, A. The characteristics, occurrence, and geochemical behavior of rare earth elements in the environment: A review. Crit. Rev. Environ. Sci. Technol. 2015, 45, 429-471. [CrossRef]

31. Liang, T.; Zhang, S.; Wang, L.; Kung, H.T.; Wang, Y.; Hu, A.; Ding, S. Environmental biogeochemical behaviors of rare earth elements in soil-plant systems. Environ. Geochem. Health 2005, 27, 301-311. [CrossRef] [PubMed]

32. Pang, X.; Li, D.; Peng, A. Application of rare-earth elements in the agriculture of China and its environmental behavior in soil Environ. Sci. Pollut. Res. 2002, 92, 143-148. [CrossRef] [PubMed]

33. US-EPA. Rare Earth Elements: A Review of Production, Processing, Recycling, and Associated Environmental Issues; EPA/600/R-12/572; United States Environmental Protection Agency: Cincinnati, OH, USA, 2012.

34. Adeel, M.; Lee, J.Y.; Zain, M.; Rizwan, M.; Nawab, A.; Ahmad, M.A.; Shafiq, M.; Yi, H.; Jilani, G.; Javed, R.; et al. Cryptic footprints of rare earth elements on natural resources and living organisms. Environ. Int. 2019, 127, 785-800. [CrossRef]

35. King, H.M. REE-Rare Earth Elments and Their Uses. Available online: https://geology.com/articles/rare-earth-elements/ (accessed on 15 November 2021).

36. MacMillan, G.A.; Chételat, J.; Heath, J.; Mickpegak, R.; Amyot, M. Rare earth elements (REE) in freshwater, marine, and terrestrial ecosystems in the eastern Canadian Arctic. Environ. Sci. Processes Impacts 2017, 19, 1336-1345. [CrossRef]

37. Souza, I.C.; Morozesk, M.; Azevedo, V.C.; Mendes, V.A.S.; Duarte, I.D.; Rocha, L.D.; Matsumoto, S.T.; Elliott, M.; Baroni, M.V.; Wunderlin, D.A.; et al. Trophic transfer of emerging metallic contaminants in a neotropical mangrove ecosystem food web. $J$. Hazard. Mater. 2021, 408, 124424. [CrossRef]

38. Lortholarie, M.; Zalouk-Vergnoux, A.; Couderc, M.; Kamari, A.; François, Y.; Herrenknecht, C. Rare earth element bioaccumulation in the yellow and silver European eel (Anguilla anguilla): A case study in the Loire estuary (France) Laurence Poirier. Sci. Total Environ. 2020, 719, 134938. [CrossRef]

39. Négrel, P.; Guerrot, C.; Cocherie, A.; Azaroual, M.; Brach, M.; Fouillac, C. Rare earth elements, neodymium and strontium isotopic systematics in mineral waters: Evidence from the Massif Central, France. Appl. Geochem. 2000, 15, 1345-1367. [CrossRef]

40. Vrel, A. Reconstitution de L'historique des Apports en Radionucléides et Contaminants Métalliques à L'estuaire Fluvial de la Seine Par L'analyse de Leur Enregistrement Sédimentaire. Ph.D. Thesis, University of Caen, Caen, France, 2012.

41. Akagi, T.; Edanami, K. Sources of rare earth elements in shells and soft tissues of bivalves from Tokyo Bay. Mar. Chem. 2017, 194, 55-62. [CrossRef]

42. Johannesson, K.H.; Palmore, C.D.; Fackrell, J.; Prouty, N.G.; Swarzenski, P.W.; Chevis, D.A.; Telfeyan, K.; White, C.D.; Burdige, D.J. Rare earth element behavior during groundwater-seawater mixing along the Kona Coast of Hawaii. Geochim. Cosmochim. Acta 2017, 198, 229-258. [CrossRef]

43. Trifuoggi, M.; Donadio, C.; Ferrara, L.; Stanislao, C.; Toscanesi, M.; Arienzo, M. Levels of pollution of rare earth elements in the surface sediments from the Gulf of Pozzuoli (Campania, Italy). Mar. Poll. Bull. 2018, 136, 374-384. [CrossRef] [PubMed]

44. Folens, K.; Du Laing, G. Dispersion and solubility of Ln, Tl, Ta and Nb in the aquatic environment and intertidal sediments of the Scheldt estuary (Flanders, Belgium). Chemosphere 2017, 183, 401-409. [CrossRef] [PubMed]

45. Censi, P.; Mazzola, S.; Sprovieri, M.; Bonanno, A.; Patti, B.; Punturo, R.; Spoto, S.E.; Saiano, F.; Alonzo, G. Rare earth elements distribution in seawater and suspended particulate of the central Mediterranean Sea. Chem. Ecol. 2004, 20, 323-343. [CrossRef]

46. Khadijeh, R.S.E.; Saion, E.; Wood, A.K.; Reza, A.M. Rare earth elements distribution in marine sediments of Malaysia coasts. J. Rare Earths 2009, 27, 1066-1071. [CrossRef]

47. Oliveri, E.; Neri, R.; Bellanca, A.; Riding, R. Carbonate stromatolites from a Messinian hypersaline setting in the Caltanissetta Basin, Sicily: Petrographic evidence of microbial activity and related stable isotope and rare earth element signatures. Sedimentology 2010, 57, 142-161. [CrossRef]

48. Lerat-Hardy, A.; Coynel, A.; Dutruch, L.; Pereto, C.; Bossy, C.; Gil-Diaz, T.; Capdeville, M.J.; Blanc, G.; Schäfe, J. Rare Earth Element fluxes over 15 years into a major European Estuary (Garonne-Gironde, SW France): Hospital effluents as a source of increasing gadolinium anomalies. Sci. Total Environ. 2019, 656, 409-420. [CrossRef] [PubMed] 
49. Kulaksız, S.; Bau, M. Anthropogenic dissolved and colloid/nanoparticle-bound samarium, lanthanum and gadolinium in the Rhine River and the impending destruction of the natural rare earth element distribution in rivers. Earth Planet. Sci. Lett. 2013, 362, 43-50. [CrossRef]

50. Zhang, J.; Wang, Z.Z.; Wu, Q.; An, Y.; Jia, H.; Shen, Y. Anthropogenic rare earth elements: Gadolinium in small catchment in Guizhou Province, Southwwest China. Int. J. Environ. Res. Publ. Health 2019, 16, 4052. [CrossRef]

51. Sholkovitz, E.R.; Szymczak, R. The estuarine chemistry of rare earth elements: Comparison of the Amazon, Fly, Sepik and the Gulf of Papua systems. Earth Planet. Sci. Lett. 2000, 179, 299-309. [CrossRef]

52. Sholkovitz, E.R. Chemical evolution of rare earth elements: Fractionation between colloidal and solution phases of filtered river water. Earth Planet. Sci. Lett. 1992, 114, 77-84. [CrossRef]

53. Evans, C.H. (Ed.) Episodes from the History of the Rare Earth Elements; Springer Science: Dordrecht, The Netherlands, 1996 ; p. 268.

54. Zhou, B.; Li, Z.; Chen, C. Global potential of rare earth resources and rare earth demand from clean technologies. Minerals 2017, 7, 203. [CrossRef]

55. Henderson, P. (Ed.) General geochemical properties, and abundances of the rare earth elements. In Rare Earth Element Geochemistry: Elsevier: Amsterdam, The Netherlands, 2011; pp. 1-29.

56. Goodenough, K.M.; Schilling, J.; Jonsson, E.; Kalvig, P.; Charles, N.; Tuduri, J.; Deady, E.A.; Sadeghi, M.; Schiellerup, H.; Müller A.; et al. Europe's rare earth element resource potential: An overview of REE metallogenetic provinces and their geodynamic setting. Ore Geol. Rev. 2016, 72, 838-856. [CrossRef]

57. Kamenopoulos, S.N.; Shields, D.; Agioutantis, Z. Sustainable development criteria and indicators for the assessment of rare earth element mining projects. In Rare Earths Industry; De Lima, I.B., Filho, W.L., Eds.; Elsevier: Amsterdam, The Netherlands, 2016; pp. 87-109.

58. Zepf, V. (Ed.) Rare earth elements: What and where they are. In Rare Earth Elements; Springer: Berlin/Heidelberg, Germany, 2013; pp. 11-39.

59. Rudnick, R.L.; Gao, S. Composition of the continental crust. In Treatise on Geochemistry; Rudnick, R.L., Holland, H.D., Turekian, K.K., Eds.; Elsevier Pergamon: Oxford, UK, 2003; Volume 3, pp. 1-7.

60. Wikipedia. Available online: https://en.wikipedia.org/wiki/Abundance_of_the_chemical_elements (accessed on 15 November 2021).

61. Kanazawa, Y.; Kamitani, M. Rare earth minerals and resources in the world. J. Alloys Compd. 2006, 408, 1339-1343. [CrossRef]

62. Trapasso, G.; Chiesa, S.; Freitas, R.; Pereira, E. What do we know about the ecotoxicological implications of the rare earth element gadolinium in aquatic ecosystems? Sci. Total Environ. 2021, 781, 146273. [CrossRef] [PubMed]

63. Castor, S.B.; Hendrik, J.B. Rare earth elements. In Industrial Minerals and Rocks: Commodities, Markets, and Uses; Kogel, J.E., Trivedi, N.C., Barker, J.M., Krukowski, S.T., Eds.; Society for Mining Mineralogy: Englewood, CO, USA, 2006; Volume 7.

64. Schüler, D.; Buchert, M.; Liu, R.; Dittrich, S.; Merz, C. Study on Rare Earths and Their Recycling. Final Report for the Greens/EFA Group in the European Parliament; The Greens/European Free Alliance, Öko-Institut e.V. Darmstadt: Frelburg, Germany, 2011 ; p. 140.

65. Binnemans, K.; Jones, P.T.; Blanpain, B.; Van Gerven, T.; Yang, Y.; Walton, A.; Buchert, M. Recycling of rare earths: A critical review. J. Clean. Prod. 2013, 51, 1-22. [CrossRef]

66. Cao, S.; Duan, X.; Ma, Y.; Zhao, X.; Qin, Y.; Liu, Y.; Li, S.; Zheng, B.; Wei, F. Health benefit from decreasing exposure to heavy metals and metalloid after strict pollution control measures near a typical river basin area in China. Chemosphere 2017, 184, 866-878. [CrossRef] [PubMed]

67. Gutiérrez-Gutiérrez, S.C.; Coulon, F.; Jiang, Y.; Wagland, S. Rare earth elements and critical metal content of extracted landfilled material and potential recovery opportunities. Waste Manag. 2015, 42, 128-136. [CrossRef] [PubMed]

68. Resende, L.V.; Morais, C.A. Study of the recovery of rare earth elements from computer monitor scraps-leaching experiments Miner. Eng. 2010, 233, 277-280. [CrossRef]

69. Ikhlayel, M. An integrated approach to establish e-waste management systems for developing countries. J. Clean. Prod. 2018, 170, 119-130. [CrossRef]

70. Kim, T.; Kim, H.; Kim, G. Tracing River water versus wastewater sources of trace elements using rare earth elements in the Nakdong River estuarine waters. Mar. Poll. Bull. 2020, 160, 111589. [CrossRef] [PubMed]

71. Pagano, G.; Aliberti, F.; Guida, M.; Oral, R.; Siciliano, A.; Trifuoggi, M.; Tommasi, F. Rare earth elements in human and animal health: State of art and research priorities. Environ. Res. 2015, 142, 215-220. [CrossRef]

72. Pagano, G.; Guida, M.; Tommasi, F.; Oral, R. Health effects and toxicity mechanisms of rare earth elements-Knowledge gaps and research prospects. Ecotoxicol. Environ. Saf. 2015, 115, 40-48. [CrossRef] [PubMed]

73. Aide, M. Lanthanide soil chemistry and its importance in understanding soil pathways: Mobility, plant uptake, and soil health Lanthanides. In Lanthanides, 23rd ed.; Awwad, N.S., Mubarak, A.T., Eds.; IntechOpen: London, UK, 2019.

74. Caccia, V.G.; Milero, J.F. Distribution of yttrium and rare earths in Florida Bay sediments. Mar. Chem. 2007, 104, 171-185 [CrossRef]

75. Sholkovitz, E.R. The aquatic chemistry of rare earth elements in rivers and estuaries. Aquat. Geochem. 1995, 1, 1-34. [CrossRef]

76. Marmolejo-Rodríguez, A.J.; Prego, R.; Meyer-Willerer, A.; Shumilin, E.; Sapozhnikov, D. Rare earth elements in iron oxy-hydroxide rich sediments from the Marabasco River-Estuary System (Pacific coast of Mexico), REE affinity with iron and aluminium. $J$. Geochem. Explor. 2007, 94, 43-51. [CrossRef]

77. Elderfield, H.; Upstill-Goddard, R.; Sholkovitz, E.R. The rare earth elements in rivers, estuaries, and coastal seas and their significance to the composition of ocean waters. Geochim. Cosmochim. Acta 1990, 54, 971-991. [CrossRef] 
78. Moermond, C.T.A.; Tijink, J.; van Wezel, A.P.; Koelmans, A.A. Distribution, speciation, and bioavailability of lanthanides in the Rhine-Meuse estuary, The Netherlands. Environ. Toxicol. Chem. 2001, 20, 1916-1926. [CrossRef]

79. Goldstein, S.J.; Jacobsen, S.B. The Nd and Sr isotopic systematics of river-water dissolved material: Implications for the sources of $\mathrm{Nd}$ and Sr in seawater. Chem. Geol. 1987, 46, 245-272. [CrossRef]

80. Goldstein, S.J.; Jacobsen, S.B. Rare earth elements in river waters. Earth Planet. Sci. Lett. 1988, 89, 35-47. [CrossRef]

81. Kulaksiz, S.; Bau, M. Rare earth elements in the Rhine River, Germany: First case of anthropogenic lanthanum as a dissolved microcontaminant in the hydrosphere. Environ. Int. 2011, 37, 973-979. [CrossRef]

82. Bau, M.; Dulski, P. Anthropogenic origin of positive gadolinium anomalies in river waters. Earth Planet. Sci. Lett. 1996, 143, 245-255. [CrossRef]

83. Tang, J.; Johannesson, K.H. Speciation of rare earth elements in natural terrestrial waters: Assessing the role of dissolved organic matter from the modeling approach. Geochim. Cosmochim. Acta 2003, 67, 2321-2339. [CrossRef]

84. Pourret, O.; Tuduri, J. Continental shelves as potential resource of rare earth elements. Sci. Rep. 2017, 7, 5857. [CrossRef] [PubMed]

85. Johannesson, K.H.; Lyons, W.B.; Bird, D.A. Rare earth element concentrations and speciation in alkaline lakes from the western USA. Geophys. Res. Lett. 1994, 21, 773-776. [CrossRef]

86. Wilde, P.; Quinby-Hunt, M.S.; Erdtmann, B.D. The whole-rock cerium anomaly: A potential indicator of eustatic sea-level changes in shales of the anoxic facies. Sediment. Geol. 1996, 101, 43-53. [CrossRef]

87. Ramesh, R.; Ramanathan, A.L.; James, R.A.; Subramaniam, V.; Jacobsen, S.B.; Holland, H.D. Rare earth elements and heavy metal distribution in estuarine sediments of east coast of India. Hydrobiologia 1999, 397, 89-99. [CrossRef]

88. Borrego, J.; López-González, N.; Carro, B.; Lozano-Soria, O. Origin of the anomalies in light and middle REE in sediments of an estuary affected by phosphogypsum wastes (south-western Spain). Mar. Pollut. Bull. 2004, 49, 1045-1053. [CrossRef]

89. Prego, R.; Caetano, M.; Bernárdez, P.; Brito, P.; Ospina-Alvarez, N.; Vale, C. Rare Earth Elements in coastal sediments of the Northern Galician Shelf: Influence of geological features. Cont. Shelf Res. 2012, 35, 75-85. [CrossRef]

90. Olmez, I.; Sholkovltz, E.R.; Hermann, D.; Eganhouse, R.P. Rare earth elements in sediments off Southern California: A new anthropogenic indicator. Environ. Sci. Technol. 1991, 25, 310-316. [CrossRef]

91. Sholkovitz, E.R. REE's in marine sediments and geochemical standards. Chem. Geol. 1990, 88, 333-347. [CrossRef]

92. Zhu, W.; Kennedy, M.; de Leer, E.W.B.; Zhou, H.; Alaerts, G.J.F.R. Distribution and modelling of rare earth elements in Chinese river sediments. Sci. Total Environ. 1997, 204, 233-243. [CrossRef]

93. Nozaki, Y.; Lerche, D.; Alibo, D.S.; Snidvongs, A. The estuarine geochemistry of rare earth elements and indium in the Chao Phraya River, Thailand. Geochim. Cosmochim. Acta 2000, 64, 3983-3994. [CrossRef]

94. Singh, P.; Rajamani, V. Geochemistry of the floodplain sediments of the Kaveri River, Southern India. J. Sed. Res. 2001, 71, 50-60. [CrossRef]

95. Chaillou, G.; Anschutz, P.; Lavaux, G.; Blanc, G. Rare earth elements in the modern sediments of the Bay of Biscay (France). Mar Chem. 2006, 100, 39-52. [CrossRef]

96. Lawrence, M.G.; Kamber, B.S. The behavior of the rare earth elements during estuarine mixing revisited. Mar. Chem. 2006, 100, 147-161. [CrossRef]

97. Censi, P.; Sprovieri, M.; Saiano, F.; Di Geronimo, S.I.; Larocca, D.; Placenti, F. The behaviour of REEs in Thailand's Mae Klong estuary: Suggestions from the Y/Ho ratios and lanthanide tetrad effects. Estuar. Coast. Shelf Sci. 2007, 71, 569-579. [CrossRef]

98. Hannigan, R.; Dorval, E.; Jones, C. The rare earth element chemistry of estuarine surface sediments in the Chesapeake Bay. Chem. Geol. 2010, 272, 20-30. [CrossRef]

99. Deepulal, P.M.; Gireesh Kumar, T.R.; Sujatha, C.H. Behaviour of REEs in a tropical estuary and adjacent continental shelf of southwest coast of India: Evidence from anomalies. J. Earth Syst. Sci. 2012, 121, 1215-1227. [CrossRef]

100. López-González, N.; Borrego, G.; Carro, B.; Grande, J.A. Rare-earth-element fractionation patterns in estuarine sediments as a consequence of acid mine drainage: A case study in SW Spain. Bol. Geol. Min. 2012, 123, 55-64.

101. Suja, S.; Fernandes, L.L.; Rao, V.P. Distribution and fractionation of rare earth elements and Yttrium in suspended and bottom sediments of the Kali estuary, western India. Environ. Earth Sci. 2017, 76, 174. [CrossRef]

102. Laukert, G.; Frank, M.; Bauch, D.; Hathorne, E.C.; Rabe, B.; von Appen, W.J.; Wegner, C.; Zieringer, M.; Kassens, H. Ocean circulation and freshwater pathways in the Arctic Mediterranean based on a combined Nd isotope, REE and oxygen isotope section across Fram Strait. Geochem. Cosmochim. Acta 2017, 202, 285-309. [CrossRef]

103. Osborne, A.H.; Haley, B.; Hathorne, E.C.; Flögel, S.; Frank, M. Neodymium isotopes and concentrations in Caribbean seawater: Tracing water mass mixing and continental input in a semi-enclosed ocean basin. Earth Planet. Sci. Lett. 2014, 406, 174-186. [CrossRef]

104. Bayon, G.; German, C.R.; Burton, K.W.; Nesbitt, R.W.; Rogers, N. Sedimentary Fe-Mn oxy-hydroxides as paleoceanographic archives and the role of aeolian flux in regulating oceanic dissolved REE. Earth Planet. Sci. Lett. 2004, 224, 477-492. [CrossRef]

105. Canet, C.; Prol-Ledesma, R.M.; Proensa, J.A.; Rubio-Ramos, M.A.; Forrest, M.J.; Torres-Vera, M.A.; Rodríguez-Díaz, A.A. Mn-BaHg mineralization at shallow submarine hydrothermal vents in Bahía, Baja California Sur, México. Chem. Geol. 2005, 224, 96-112. [CrossRef]

106. Sifeta, K.; Roser, B.P.; Kimura, J.I. Geochemistry, provenance, and tectonic setting of Neoproterozoic metavolcanic and metasedimentary units, Werri area, Northern Ethiopia. J. Afr. Earth Sci. 2005, 41, 212-234. [CrossRef]

107. Brookins, D. Aqueous geochemistry of rare earth elements. Rev. Miner. Geochem. 1989, 21, 201-225. 
108. Saha, N.; Webb, G.E.; Zhao, J.X.; Lewis, S.E.; Nguyen, A.D.; Feng, Y. Spatiotemporal variation of rare earth elements from river to reef continuum aids monitoring of terrigenous sources in the Great Barrier Reef. Geoch. Cosm. Acta 2021, 299, 85-112. [CrossRef]

109. Wilke, C.; Barkleit, A.; Stumpf, T.; Ikeda-Ohno, A. Speciation of the trivalent elements Eu(III) and Cm(III) in digestive media. J. Inorg. Biochem. 2017, 175, 248-258. [CrossRef]

110. Sklyarova, O.A.; Sklyarov, E.V.; Och, L.; Pastukhov, M.V.; Zagorulko, N.A. Rare earth elements in tributaries of lake Baikal (Siberia, Russia). Appl. Geochem. 2017, 82, 164-176. [CrossRef]

111. Sholkovitz, E. Flocculation of dissolved organic and inorganic matter during the mixing of river water and seawater. Geochim. Cosmochim. Acta 1976, 40, 831-845. [CrossRef]

112. Delgado, J.; Pérez-López, R.; Galván, L.; Nieto, J.M.; Boski, T. Enrichment of rare earth elements as environmental tracers of contamination by acid mine drainage in salt marshes: A new perspective. Mar. Pollut. Bull. 2012, 64, 1799-1808. [CrossRef] [PubMed]

113. Schijf, J.; Christenson, E.A.; Byrne, R.H. YREE scavenging in seawater: A new look at an old model. Mar. Chem. 2015, 177, 460-471. [CrossRef]

114. Borrego, J.; López-González, N.; Carro, B.; Lozano-Soria, O. Geochemistry of rare-earth elements in Holocene sediments of an acidic estuary: Environmental markers (Tinto River estuary, South-western Spain). J. Geochem. Explor. 2005, 86, 119-129. [CrossRef]

115. Byrne, R.H.; Kim, K.H. Rare-Earth element scavenging in seawater. Geochim. Cosmochim. Acta 1990, 54, 2645-2656. [CrossRef]

116. Sholkovitz, E.R.; Landing, W.M.; Lewis, B.L. Ocean particle chemistry: The fractionation of rare earth elements between suspended particles and seawater. Geochim. Cosmochim. Acta 1994, 58, 1567-1579. [CrossRef]

117. Bau, M. Controls on the fractionation of isovalent trace elements in magmatic and aqueous systems: Evidence from $\mathrm{Y} / \mathrm{Ho}, \mathrm{Zr} / \mathrm{Hf}$, and lanthanide tetrad effect. Contrib. Mineral. Petrol. 1996, 123, 323-333. [CrossRef]

118. Sholkovitz, E.R. Artifacts associated with the chemical leaching of sediments for rare-earth elements. Chem. Geol. 1989, 77, 47-51. [CrossRef]

119. Andrade, R.L.B.; Hatje, V.; Pedreira, R.M.A.; Böning, P.; Pahnke, K. REE fractionation and human Gd footprint along the continuum between Paraguaçu River to coastal South Atlantic waters. Chem. Geol. 2020, 532, 119303. [CrossRef]

120. Merschel, G.; Bau, M.; Dantas, E.L. Contrasting impact of organic and inorganic nanoparticles and colloids on the behavior of particle-reactive elements in tropical estuaries: An experimental study. Geochim. Cosmochim. Acta 2017, 197, 1-13. [CrossRef]

121. Chakraborty, P.; Raghunadh Babu, P.V.; Sarma, V.V. A multi-method approach for the study of lanthanum speciation in coastal and estuarine sediments. J. Geochem. Explor. 2011, 110, 225-231. [CrossRef]

122. Zhang, C.; Wang, L.; Zhang, S.; Li, X. Geochemistry of rare earth elements in the mainstream of the Yangtze River, China. Appl. Geochem. 1998, 13, 451-462. [CrossRef]

123. Rezaee, K.; Saion, E.B.; Wood, A.K.; Abdi, M.R. Rare earth elements determination and distribution patterns in surface marine sediments of the South China Sea by INAA. Malays. J. Radioanal. Nucl. Chem. 2010, 283, 823-829. [CrossRef]

124. Shynu, R.; Purnachandra Rao, V.; Kessarkar, P.M.; Rao, T.G. Rare earth elements in suspended and bottom sediments of the Mandovi estuary, central west coast of India: Influence of mining Estuarine. Coast. Shelf Sci. 2011, 94, 355-368. [CrossRef]

125. Hu, G.; Lin, C.; Yang, Q.; Yan, Y.; Huang, H.; Yu, R.; Cui, J.; Yan, Y. Distribution and ratioointment of rare earth elements in offshore sediments of Western Xiamen Bay, Southeast China. J. Geochem. Expl. 2019, 201, 31-39. [CrossRef]

126. Rivas-Sanchez, M.L.; Alva-Valdivia, L.M.; Arenas-Alatorre, J.; Urrutia-Fucugauchi, J.; Ruiz-Sandoval, M.; Ramos-Molina, M.A. Berthierine and chamosite hydrothermal: Genetic guides in the Peña Colorada magnetite-bearing ore deposit, Mexico. Earth Planets Space 2006, 58, 1389-1400. [CrossRef]

127. Weltje, L.; Heidenreich, H.; Zhu, W.; Wolterbeek, H.T.; Korhammer, S.; Goeij, J.J.M.; Markert, B. Lanthanide concentrations in freshwater plants and molluscs, related to those in surface water, pore water and sediment. A case study in The Netherlands. Sci. Total Environ. 2002, 286, 191-214. [CrossRef]

128. Zhang, S.; Shan, X.Q. Speciation of rare earth elements in soil and accumulation by wheat with rare earth fertilizer application Environ. Pollut. 2001, 112, 395-405. [CrossRef]

129. Strady, E.; Kim, I.; Radakovitch, O.; Kim, G. Rare earth element distributions and fractionation in plankton from the northwestern Mediterranean Sea. Chemosphere 2015, 119, 72-82. [CrossRef]

130. Figueiredo, C.; Grilo, T.F.; Lopes, C.; Brito, P.; Diniz, M.; Caetano, M.; Rosa, R.; Raimundo, J. Accumulation, elimination and neuro-oxidative damage under lanthanum exposure in glass eels (Anguilla anguilla). Chemosphere 2018, 206, 414-423. [CrossRef]

131. Censi, P.; Randazzo, L.A.; D’Angelo, S.; Saiano, F.; Zuddas, P.; Mazzola, S.; Cuttitta, A. Relationship between lanthanide contents in aquatic turtles and environmental exposures. Chemosphere 2013, 91, 1130-1135. [CrossRef]

132. Mayfield, D.B.; Fairbrother, A. Examination of rare earth element concentration patterns in freshwater fish tissues. Chemosphere 2015, 120, 68-74. [CrossRef] [PubMed]

133. Yang, L.; Wang, X.; Nie, H.; Shao, L.; Wang, G.; Liu, Y. Residual levels of rare earth elements in freshwater and marine fish and their health risk assessment from Shandong, China. Mar. Pollut. Bull. 2016, 107, 393-397. [CrossRef] [PubMed]

134. Khan, A.M.; Behkami, S.; Yusoff, I.; Md Zain, S.B.; Bakar, N.K.A.; Bakar, A.F.A.; Alias, Y. Geochemical characteristics of rare earth elements in different types of soil: A chemometric approach. Chemosphere 2017, 184, 673-678. [CrossRef] [PubMed]

135. Bustamante, P.; Miramand, P. Subcellular and body distributions of 17 trace elements in the variegated scallop Chlamys varia from the French coast of the Bay of Biscay. Sci. Total Environ. 2005, 337, 59-73. [CrossRef] [PubMed] 
136. Palmer, A.S.; Snape, I.; Stark, J.S.; Johnstone, G.J.; Townsend, A.T. Baseline metal concentrations in Paramoera walkeri from East Antarctica. Mar. Pollut. Bull. 2006, 52, 1441-1449. [CrossRef]

137. Riget, F.; Johansen, P.; Asmund, G. Influence of length on element concentrations in blue mussels (Mytilus edulis). Mar. Pollut. Bull. 1996, 32, 745-751. [CrossRef]

138. Nørregaard, R.D.; Kaarsholm, H.; Bach, L.; Nowak, B.; Geertz-Hansen, O.; Søndergaard, J.; Sonne, C. Bioaccumulation of rare earth elements in juvenile arctic char (Salvelinus alpinus) under field experimental conditions. Sci. Total Environ. 2019, 688, 529-535. [CrossRef]

139. Ma, L.; Dang, D.H.; Wang, W.; Evans, R.D.; Wang, W.X. Rare earth elements in the Pearl River Delta of China: Potential impacts of the REE industry on water, suspended particles, and oysters. Environ. Pollut. 2019, 244, 190-201. [CrossRef]

140. Jiao, Y.; Yang, L.; Kong, Z.; Shao, L.; Wang, G.; Ren, X.; Liu, Y. Evaluation of trace metals and rare earth elements in mantis shrimp Oratosquilla oratoria collected from Shandong Province, China, and its potential risks to human health. Mar. Poll. Bull. 2021, 162, 111815. [CrossRef]

141. Menegario, A.A.; Yabuki, L.N.M.; Luko, K.S.; Williams, P.N.; Blackburn, D.M. Use of diffusive gradient in thin films for in situ measurements: A review on the progress in chemical fractionation, speciation, and bioavailability of metals in waters. Anal. Chim. Acta 2017, 983, 54-66. [CrossRef]

142. Cánovas, C.R.; Basallote, M.D.; Macías, F. Distribution and availability of rare earth elements and trace elements in the estuarine waters of the Ría of Huelva (SW Spain). Environ. Poll. 2020, 267, 115506. [CrossRef] [PubMed]

143. Linde, A.R.; Arribas, P.; Sanchez-Galan, S.; Garcia-Vazquez, F. Eel (Anguilla anguilla) and brown trout (Salmo trutta) target species to assess the biological impact of trace metal pollution in freshwater ecosystems. Arch. Environ. Contam. Toxicol. 1996, 31, 297-302. [CrossRef]

144. Durrieu, G.; Maury-Brachet, R.; Girardin, M.; Rochard, E.; Boudou, A. Contamination by heavy metals (Cd, Zn, Cu, and Hg) of eight fish species in the Gironde estuary (France). Estuaries 2005, 28, 581-591. [CrossRef]

145. Lortholarie, M.; Poirier, L.; Kamari, A.; Herrenknecht, C.; Zalouk-Vergnoux, A. Rare earth element organotropism in European eel (Anguilla anguilla). Sci. Total Environ. 2021, 766, 142513. [CrossRef]

146. Pernice, M.; Boucher, J.; Boucher-Rodoni, R.; Joannot, P.; Bustamante, P. Comparative bioaccumulation of trace elements between Nautilus pompilius and Nautilus macromphalus (Cephalopoda: Nautiloidea) from Vanuatu and NewCaledonia. Ecotoxicol. Environ. Saf. 2009, 72, 365-371. [CrossRef]

147. Ichihashi, H.; Kohno, H.; Kannan, K.; Tsumura, A.; Yamasaki, S.I. Multi-elemental analysis of purple back flying squid using high resolution inductively coupled plasma-mass spectrometry (HR ICP-MS). Environ. Sci. Technol. 2001, 35, 3103-3108. [CrossRef] [PubMed]

148. Chassard-Bouchard, C.; Hallegot, P. Bioaccumulation de lanthane par desmoulesMytilus edulis(L) récoltées sur les côtes françaises. Microanalyse parspectrographie des rayons X et par émission ionique secondaire. Acad. Sci. III 1984, $298,567-572$.

149. Lavezzo, B.; Kinoshita, A.; Figueiredo, A.M.G.; Faita Pinheiro, M.M.; Santana, W. Detection of rare-earth elements using fiddler crabs Leptuca leptodactyla (Crustacea: Ocypodidae) as bioindicators in mangroves on the coast of São Paulo, Brazil. Sci. Total Environ. 2020, 738, 139787. [CrossRef] [PubMed]

150. Natálio, L.F.; Pardo, J.C.; Machado, G.B.; Fortuna, M.D.; Gallo, D.G.; Costa, T.M. Potential effect of fiddler crabs on organic matter distribution: A combined laboratory and field experimental approach. Estuar. Coast. Shelf Sci. 2017, 184, 158-165. [CrossRef]

151. Ng, J.S.; Lui, K.K.; Lai, C.H.; Leung, K.M. Harpiosquilla harpax (Crustacea, Stomatopoda) as a biomonitor of trace metal contamination in benthic sediments in Hong Kong waters. Mar. Pollut. Bull. 2007, 54, 1523-1529. [CrossRef]

152. Bonnail, E.; Perez-López, R.; Sarmiento, A.M.; Nieto, J.M.; Del Valls, T.A. A novel approach for acid mine drainage pollution biomonitoring using rare earth elements bioaccumulated in the freshwater clam Corbicula fluminea. J. Hazard. Mater. 2017, 338, 466-471. [CrossRef] [PubMed]

153. Dang, D.H.; Schaefer, J.; Brach-Papa, C.; Lenoble, V.; Durrieu, G.; Dutruch, L.; Chiffoleau, J.F.; Gonzalez, J.L.; Blanc, G.; Mullot, J.U.; et al. Evidencing the impact of coastal contaminated sediments on mussels. Environ. Sci. Technol. 2015, 49, 11438-11448. [CrossRef] [PubMed]

154. Bridges, C.C.; Zalups, R.K. Molecular and ionic mimicry and the transport of toxic metals. Toxicol. Appl. Pharmacol. 2005, 204, 274-308. [CrossRef] [PubMed]

155. Evans, C.H. Interesting and useful biochemical properties of lanthanides. Trends Biochem. Sci. 1983, 8, 445-449. [CrossRef]

156. Wang, S.C. PCNA: A silent housekeeper or a potential therapeutic target? Trends Pharmacol. Sci. 2014, 35, 178-186. [CrossRef] [PubMed]

157. Li, Z.; Zhang, Z.; Jiang, W.; Yu, M.; Zhou, Y.; Zhao, Y.; Chai, Z. Direct measurement of lanthanum uptake and distribution in internodal cells of Chara. Plant Sci. 2008, 174, 496-501. [CrossRef]

158. Palasz, A.; Czekaj, P. Toxicological and cytophysiological aspects of lanthanides action. Acta Biochim. Pol. 2000, 47, 1107-1114. [CrossRef]

159. Barry, M.J.; Meehan, B.J. The acute and chronic toxicity of lanthanum to Daphnia carinata. Chemosphere 2000, 41, 1669-1674. [CrossRef]

160. Borgmann, U.; Couillard, Y.; Doyle, P.; Dixon, D.G. Toxicity of sixty-three metals and metalloids to Hyalella Azteca at two levels of water hardness. Environ. Toxicol. Chem. 2005, 24, 641-652. [CrossRef] 
161. European Commission. Directive of the European Parliament and of the Council on Environmental Quality Standards in the Field of Water Policy and Amending Directive 2000/60/EC; COM 2006398 final; European Commission: Brussels, Belgium, 2000 ; p. 25.

162. Tang, J.; Johannesson, K.H. Ligand extraction of rare earth elements from aquifer sediments: Implications for rare earth element complexation with organic matter in natural waters. Geochim. Cosmochim. Acta 2010, 74, 6690-6705. [CrossRef]

163. Zhao, C.M.; Wilkinson, K.J. Biotic ligand model does not predict the bioavailability of rare earth elements in the presence of organic ligands. Environ. Sci. Technol. 2015, 49, 2207-2214. [CrossRef] [PubMed]

164. Amyot, M.; Clayden, M.G.; Macmillan, G.A.; Perron, T.; Arscott-Gauvin, A. Fate and trophic transfer of rare earth elements in temperate lake food webs. Environ. Sci. Technol. 2017, 51, 6009-6017. [CrossRef] [PubMed]

165. Reindl, A.R.; Falkowska, L. Trace elements in the muscle, ova and seminal fluid of key clupeid representatives from the Gdansk Bay (South Baltic Sea) and Iberian Peninsula (North-East Atlantic). J. Trace Elem. Med. Biol. 2021, 68, 126803. [CrossRef] [PubMed]

166. Kumar, K.; Saion, E.; Halimah, M.K.; Yap, C.K.; Hamzah, M.S. Rare earth element (REE) in surface mangrove sediment by instrumental neutron activation analysis. J. Radioanal. Nucl. Chem. 2014, 301, 667-676. [CrossRef]

167. Li, J.-X.; Zheng, L.; Sun, C.-J.; Jiang, F.-H.; Yin, X.-F.; Chen, J.-H.; Han, B.; Wang, X.-R. Study on ecological and chemical properties of rare earth elements in tropical marine organisms. Chin. J. Anal. Chem. 2016, 44, 1539-1546. [CrossRef]

168. Carpenter, D.; Boutin, C.; Allison, J.E.; Parsons, J.L.; Ellis, D.M. Uptake and effects of six rare earth elements (REEs) on selected native and crop species growing in contaminated soils. PLoS ONE 2015, 10, e0129936. [CrossRef] [PubMed]

169. Tyler, G. Rare earth elements in soil and plant systems-A review. Plant Soil 2004, 267, 191-206. [CrossRef]

170. Liu, D.; Wang, Z. Influence of rare earth elements on chemical transformation of nitrogen in agricultural soil. J. Appl. Ecol. 2001, $124,545-548$

171. Herrmann, H.; Nolde, J.; Berger, S.; Heise, S. Aquatic ecotoxicity of lanthanum-A review and an attempt to derive water and sediment quality criteria. Ecotoxicol. Environ. Saf. 2016, 124, 213-238. [CrossRef]

172. González, V.; Vignati, D.A.L.; Leyval, C.; Giamberini, L. Environmental fate and ecotoxicity of lanthanides: Are they a uniform group beyond chemistry? Environ. Int. 2014, 71, 148-157. [CrossRef]

173. Trifuoggi, M.; Pagano, G.; Guida, M.; Palumbo, A.; Siciliano, A.; Gravina, M.; Lyons, D.M.; Burić, P.; Levak, M.; Thomas, P.J.; et al Comparative toxicity of seven rare earth elements in sea urchin early life stages. Environ. Sci. Pollut. Res. 2017, 24, 20803-20810. [CrossRef] [PubMed]

174. Martino, C.; Costa, C.; Roccheri, M.C.; Koop, D.; Scudiero, R.; Byrne, M. Gadolinium perturbs expression of skeletogenic genes, calcium uptake and larval development in phylogenetically distant sea urchin species. Aquat. Toxicol. 2018, $194,57-66$.

175. Blaise, C.; Gagné, F.; Harwood, M.; Quinn, B.; Hanana, H. Ecotoxicity responses of the freshwater cnidarian Hydra attenuata to 11 rare earth elements. Ecotoxicol. Environ. Saf. 2018, 163, 486-491. [CrossRef] [PubMed]

176. Freitas, R.; Cardoso, C.; Costa, S.; Morais, T.; Moleiro, P.; Lima, A.F.D.; Soares, M.; Figueiredo, S.; Águeda, T.L.; Rocha, P.; et al New insights on the impacts of e-waste towards marine bivalves: The case of the rare earth element dysprosium. Environ. Pollut. 2020, 260, 113859. [CrossRef] [PubMed]

177. Freitas, R.; Costa, S.; Cardoso, C.E.; Morais, T.; Moleiro, P.; Matias, A.C.; Pereira, A.F.; Machado, J.; Correia, B.; Pinheiro, D.; et al. Toxicological effects of the rare earth element neodymium in Mytilus galloprovincialis. Chemosphere 2020, 244, 125457. [CrossRef]

178. Tseng, M.T.; Lu, X.; Duan, X.; Hardas, S.S.; Sultana, R.; Wu, P.; Unrine, J.M.; Graham, U.; Butterfield, D.A.; Grulke, E.A.; et al Alteration of hepatic structure and oxidative stress induced by intravenous nanoceria. Toxicol. Appl. Pharmacol. 2012, 260, 173-182. [CrossRef] [PubMed]

179. Wang, C.; Luo, X.; Tian, Y.; Xie, Y.; Wang, S.; Li, Y.; Tian, L.; Wang, X. Biphasic effects of lanthanum on Vicia faba L. seedlings under cadmium stress, implicating finite antioxidation and potential ecological risk. Chemosphere 2012, 86, 530-537. [CrossRef]

180. Zhao, H.; Hong, J.; Yu, X.; Zhao, X.; Sheng, L.; Ze, Y.; Sang, X.; Gui, S.; Sun, Q.; Wang, L.; et al. Oxidative stress in the kidney injury of mice following exposure to lanthanides trichloride. Chemosphere 2013, 93, 875-884. [CrossRef]

181. Hongyan, G.; Liang, C.; Xiaorong, W.; Ying, C. Physiological responses of Carassius auratus to ytterbium exposure. Ecotoxicol. Environ. Saf. 2002, 53, 312-316. [CrossRef]

182. Oral, R.; Bustamante, P.; Warnau, M.; D’Ambra, A.; Guida, M.; Pagano, G. Cytogenetic and developmental toxicity of cerium and lanthanum to sea urchin embryos. Chemosphere 2010, 81, 194-198. [CrossRef]

183. González, V.; Vignati, D.A.L.; Pons, M.N.; Montarges-Pelletier, E.; Bojic, C.; Giamberini, L. Lanthanide ecotoxicity: First attempt to measure environmental risk for aquatic organisms. Environ. Pollut. 2015, 199, 139-147. [PubMed]

184. Hua, D.; Wang, J.; Yu, D.; Liu, J. Lanthanum exerts acute toxicity and histopathological changes in gill and liver tissue of rare minnow (Gobiocypris rarus). Ecotoxicology 2017, 26, 1207-1215. [CrossRef] [PubMed]

185. Mestre, N.C.; Serrão Sousam, V.; Lopes Rocha, T.; Bebianno, M.J. Ecotoxicity of rare earths in the marine mussel Mytilus galloprovincialis and a preliminary approach to assess environmental risk. Ecotoxicology 2019, 28, 294-301. [CrossRef] [PubMed]

186. Campbell, P.G.C. Interactions between trace metals and aquatic organisms: A critique of the free-ion activity model. In Metal Speciation and Bioavailability in Aquatic Systems; Tessier, A., Turner, D.R., Eds.; John Wiley \& Sons: London, UK, 1995; pp. 45-102.

187. Huang, Q.; Bu, Q.; Zhong, W.; Shi, K.; Cao, Z.; Yu, G. Derivation of aquatic predicted no-effect concentration (PNEC) for ibuprofen and sulfamethoxazole based on various toxicity endpoints and the associated risks. Chemosphere 2018, 193, 223-229. [CrossRef] [PubMed] 
188. Aharchaou, I.; Beaubien, C.; Campbell, P.G.C.; Fortin, F. Lanthanum and cerium toxicity to the freshwater green alga chlorella fusca: Applicability of the biotic ligand model. Environ. Toxicol. Chem. 2020, 39, 996-1005. [CrossRef] [PubMed]

189. El-Akl, P.; Smith, S.; Wilkinson, K.J. Linking the chemical speciation of cerium to its bioavailability in water for a freshwater alga Environ. Toxicol. Chem. 2015, 34, 1711-1719. [CrossRef]

190. Lürling, M.; Tolman, Y. Effects of lanthanum and lanthanum-modified clay on growth, survival, and reproduction of Daphnia magna. Water Res. 2010, 44, 309-319. [CrossRef]

191. Joonas, E.; Aruoja, V.; Olli, K.; Syvertsen-Wiig, G.; Vija, H.; Kahru, A. Potency of (doped) rare earth oxide particles and their constituent metals to inhibit algal growth and induce direct toxic effects. Sci. Total Environ. 2017, 593, 478-486. [CrossRef]

192. Mebane, C.A.; Chowdhury, M.J.; De Schamphelaere, K.A.C.; Lofts, S.; Paquin, P.R.; Santore, R.C.; Wood, C.M. Metal bioavailability models: Current status, lessons learned, considerations for regulatory use, and the path forward. Environ. Toxicol. Chem. 2020, 39, 60-84. [CrossRef]

193. Blinova, I.; Lukjanova, A.; Muna, M.; Vija, H.; Kahru, A. Evaluation of the potential hazard of lanthanides to freshwater microcrustaceans. Sci. Total Environ. 2018, 642, 1100-1107. [CrossRef] [PubMed]

194. Weltje, L.; Verhoof, L.R.C.W.; Verweij, W.; Hamers, T. Lutetium speciation and toxicity in a microbial bioassay: Testing the free-ion model for lanthanides. Environ. Sci. Technol. 2004, 38, 6597-6604. [CrossRef] [PubMed]

195. Tan, Q.G.; Yang, G.; Wilkinson, K.J. Biotic ligand model explains the effects of competition but not complexation for Sm biouptake by Chlamydomonas reinhardtii. Chemosphere 2017, 168, 426-434. [CrossRef] [PubMed]

196. Yang, Y.; Walton, A.; Sheridan, R.; Güth, K.; Gauß, R.; Gutfleisch, O.; Buchert, M.; Steenari, B.M.; Van Gerven, T.; Jones, P.T.; et al. REE recovery from end-of-life NdFeB permanent magnet scrap: A critical review. J. Sustain. Metall. 2016, 3, 122-149. [CrossRef]

197. Tai, P.; Zhao, Q.; Su, D.; Li, P.; Stagnitti, F. Biological toxicity of lanthanide elements on algae. Chemosphere 2010, 80, 1031-1035 [CrossRef] [PubMed]

198. Atibu, E.K.; Devarajan, N.; Laffite, A.; Giuliani, G.; Salumu, J.A.; Muteb, R.C.; Mulaji, C.K.; Otamonga, J.P.; Elongo, V.; Mpiana, P.T.; et al. Assessment of trace metaland rare earth elements contamination in rivers around abandoned and activemine areas. The case of Lubumbashi River and Tshamilemba Canal, Katanga, Democratic Republic of the Congo. Geochemistry 2016, 76, 353-362. [CrossRef]

199. Lompré, J.S.; Moleiro, P.; De Marchi, L.; Soares, A.M.V.M.; Pretti, C.; Chielini, F.; Pereira, E.; Freitas, R. Bioaccumulation and ecotoxicological responses of clams exposed to terbium and carbon nanotubes: Comparison between native (Ruditapes decussatus) and invasive (Ruditapes philippinarum) species. Sci. Total Environ. 2021, 784, 146914. [CrossRef]

200. Rabiet, M.; Letouzet, M.; Hassanzadeh, S.; Simon, S. Transmetallation of Gd-DTPA by Fe ${ }^{3+}, \mathrm{Cu}^{2+}$ and $\mathrm{Zn}^{2+}$ in water: Batch experiments and coagulation-flocculation simulations. Chemosphere 2014, 95, 639-642. [CrossRef]

201. Möller, P.; Morteani, G.; Dulski, P. Anomalous gadolinium, cerium, and Yttrium contents in the Adige and Isarco River waters and in the water of their tributaries (Provinces Trento and Bolzano/Bozen, NE Taly). Acta Hydrochim. Hydrobiol. 2003, 31, 225-239. [CrossRef]

202. Dulski, P.; Möller, P.; Pekdeger, A. Comparison of gadopentetic acid (Gd-DTPA) and bromide in a dual-tracer filed experiment. Hydrogeol. J. 2011, 19, 823-834. [CrossRef]

203. Telgmann, L.; Wehe, C.A.; Künnemeyer, J.; Bülter, A.-C.; Sperling, M.; Karst, U. Speciation of Gd-based MRI contrast agents and potential products of transmetalation with iron ions or parenteral iron supplements. Anal. Bioanal. Chem. 2012, 404, 2133-2141. [CrossRef]

204. Nozaki, Y.; Lerche, D.; Alibo, D.S.; Tsutsumi, M. Dissolved indium and rare earth elements in three Japanese rivers and Tokyo Bay: Evidence for anthropogenic Gd and In. Geochem. Cosmochim. Acta 2000, 64, 3975-3982. [CrossRef]

205. Bau, M.; Knappe, A.; Dulski, P. Anthropogenic gadolinium as a micropollutant in river waters in Pennsylvania and in Lake Erie, northeastern United States. Chem. Erde-Geochem. 2006, 66, 143-152. [CrossRef]

206. Lawrence, M.G. Detection of anthropogenic gadolinium in the Brisbane River plume in Moreton Bay, Queensland, Australia. Mar. Pollut. Bull. 2010, 60, 1113-1116. [CrossRef] [PubMed]

207. Hatje, V.; Bruland, K.W.; Flegal, A.R. Increases in anthropogenic gadolinium anomalies and rare earth element concentrations in San Francisco Bay over a 20 year record. Environ. Sci. Technol. 2016, 50, 4159-4168. [CrossRef] [PubMed]

208. Rousseau, T.C.; Sonke, J.E.; Chmeleff, J.; Van Beek, P.; Souhaut, M.; Boaventura, G.; Seyler, P.; Jeandel, C. Rapid neodymium release to marine waters from lithogenic sediments in the Amazon estuary. Nat. Commun. 2015, 6, 7592. [CrossRef] [PubMed]

209. Kulaksız, S.; Bau, M. Contrasting behaviour of anthropogenic gadolinium and natural rare earth elements in estuaries and the gadolinium input into the North Sea. Earth Plan. Sci. Lett. 2007, 260, 361-371. [CrossRef]

210. Schijf, J.; Christy, I.J. Effect of Mg and Ca on the stability of the MRI contrast agent Gd-DTPA in seawater. Front. Mar. Sci. 2018, 5, 111. [CrossRef]

211. Henriques, B.; Coppola, F.; Monteiro, R.; Pinto, J.; Viana, T.; Pretti, C.; Soares, A.; Freitas, R.; Pereira, E. Toxicological assessment of anthropogenic Gadolinium in seawater: Biochemical effects in mussels Mytilus galloprovincialis. Sci. Total Environ. 2019, 664, 626-634. [CrossRef]

212. Fujita, Y.; Walton, M.; Das, G.; Dohnalkova, A.; Vanzin, G.; Anderko, A. Impacts of anthropogenic gadolinium on the activity of the ammonia oxidizing bacterium Nitrosomonas europaea. Chemosphere 2020, 257, 127250. [CrossRef]

213. Martino, C.; Bonaventura, R.; Byrne, M.; Roccheri, M.; Matranga, V. Effects of exposure to gadolinium on the development of geographically and phylogenetically distant sea urchin's species. Mar. Environ. Res. 2017, 128, 98-106. [CrossRef] 
214. Martino, C.; Chiarelli, R.; Bosco, L.; Roccheri, M.C. Induction of skeletal abnormalities and autophagy in Paracentrotus lividus sea urchin embryos exposed to gadolinium. Mar. Environ. Res. 2017, 130, 12-20. [CrossRef]

215. Merschel, G.; Bau, M. Rare earth elements in the aragonitic shell of freshwater mussel Corbicula fluminea and the bioavailability of anthropogenic lanthanum, samarium and gadolinium in river water. Sci. Total Environ. 2015, 533, 91-101. [CrossRef]

216. Merschel, G.; Bau, M.; Baldewein, L.; Dantas, E.L.; Walde, D.; Bühn, B. Tracing and tracking wastewater-derived substances in freshwater lakes and reservoirs: Anthropogenic gadolinium and geogenic in Lake Paranoá, Brasilia. Compt. Rendus Geosci. 2015, 3475, 284-293. [CrossRef]

217. Olias, M.; Ceron, J.C.; Fernandez, I.; De La Rosa, J. Distribution of rare earth elements in an alluvial aquifer affected by acid mine drainage: The Guadiamar aquifer (SW Spain). Environ. Pollut. 2005, 135, 53-64. [PubMed]

218. Åström, M.E.; Österholm, P.; Gustafsson, J.P.; Nystrand, M.; Peltola, P.; Nordmyr, L.; Boman, A. Attenuation of rare earth elements in a boreal estuary. Geochim. Cosmochim. Acta 2012, 96, 105-119. [CrossRef]

219. Das, T.; Sharma, A.; Talukder, G. Effects of lanthanum in cellular systems.Biolo. Trace Elem. Res. 1988, 18, 201-228. [CrossRef] [PubMed]

220. Pinto, J.; Costa, M.; Leite, C.; Borges, C.; Coppola, F.; Henriques, B.; Monteiro, R.; Russo, T.; Di Cosmo, A.; Soares, A.M.V.M.; et al. Ecotoxicological effects of lanthanum in Mytilus galloprovincialis: Biochemical and histopathological impacts. Aquat. Toxicol. 2019, 211, 181-192. [CrossRef] [PubMed]

221. Tomlinson, G.; Mutus, B.; McLennan, I.; Mooibroek, M.J. Activation and in-activation of purified acetylcholinesterase from Electrophorus electricus by lanthanum(III). Biochim. Biophys. Acta Protein Struct. Mol. Enzymol. 1982, 703, 142-148. [CrossRef]

222. Hong, F.; Wang, L.; Liu, C.; Su, M.; Huang, H.; Chen, L. Prevention of La3ponDNA Damage Caused by Hg2pfrom Fish Intestines J. Rare Earths 2007, 25, 243-248. [CrossRef]

223. Verbost, P.M.; Flik, G.; Lock, R.A.; Wendelaar Bonga, S.E. Cadmium inhibition of $\mathrm{Ca}^{2+}$ uptake in rainbow trout gills. Am. J. Physiol. 1987, 253, 216-221.

224. Block, M.; Pärt, P. Uptake of 109Cd by cultured gill epithelial cells from rain-bow trout (Oncorhynchus mykiss). Aquat. Toxicol. 1992, 23, 137-151. [CrossRef]

225. Wang, Y.; Jin, H.; Deng, S.; Chen, Y.; Yu, Y. Effect of neodymium on growth and physiological characteristics of Microcystis aeruginosa. J. Rare Earths 2011, 29, 388-395. [CrossRef]

226. Wang, C.; Zhu, W.; Wang, Z.; Guicherit, R. Rare earth elements and other metals in atmospheric particulate matter in the western part of the Netherlands. Water Air Soil Pollut. 2000, 121, 109-118. [CrossRef]

227. Jenkins, W.; Perone, P.; Walker, K.; Bhagavathula, N.; Aslam, M.N.; Da Silva, M.; Dame, M.K.; Varani, J. Fibroblast response to lanthanoid metalion stimulation: Potential contribution to fibrotic tissue injury. Biol. Trace Elem. Res. 2011, 144, 621-635. [CrossRef] [PubMed]

228. Campbell, L.M.; Norstrom, R.J.; Hobson, K.A.; Muir, D.C.G.; Backus, S.; Fisk, A.T. Mercury and other trace elements in a pelagic Arctic marine food web (North water Polynya, Baffin Bay). Sci. Total Environ. 2005, 351, 247-263. [CrossRef]

229. Constantinides, S. The Demand for Rare Earth Materials in Permanent Magnets. In Proceedings of the 51st Annual Conference of Metallurgists COM Niagara Falls, Niagara Falls, NY, USA, 30 September-3 October 2012.

230. Haque, N.; Hughes, A.; Lim, S.; Vernon, C. Rare earth elements: Overview of mining, mineralogy, uses, sustainability, and environmental impact. Resources 2014, 34, 614-635. [CrossRef]

231. Stegen, K.S. Heavy rare earths, permanent magnets, and renewable energies: An imminent crisis. Energy Policy 2015, 79, 1-8. [CrossRef]

232. PV Magazine. Available online: https://www.pv-magazine.com/2021/05/07/recycling-rare-earth-elements-in-dead-lithiumbatteries/. (accessed on 15 November 2021).

233. Chakhmouradian, A.R.; Wall, F. Rare Earth Elements: Minerals, mines, magnets (and more). Elements 2012, 8, 333-340. [CrossRef]

234. Bonawandt, C. Recycling Rare Earth Metals Presents Challenges, Opportunities. Engineering.com $2013 . \quad$ Available online: https:/ / www.engineering.com/Blogs/tabid/3207/ArticleID/5693/Recycling-Rare-Earth-Metals-Presents-ChallengesOpportunities.aspx?e_src=relart (accessed on 26 October 2021).

235. Hono, K.; Sepehri-Amin, H. Prospect for HRE-free high coercivity Nd-Fe-B permanent magnets. Scr. Mater. 2018, 151, 6-13. [CrossRef]

236. Abrenica, G.H.A.; Ocon, J.D.; Lee, J. Dip-coating synthesis of high-surface area nanostructured FeB for direct usage as anode in metal/metalloid-air battery. Curr. Appl. Phys. 2016, 16, 1075-1080. [CrossRef] 